\title{
Resumos de Dissertações de Mestrado e Teses de Doutorado apresentadas na Faculdade de Medicina de Ribeirão Preto - USP de janeiro a março de 2012
}

\author{
Biologia Celular e Molecular
}

\section{EXPRESSÃO DE UM FRAGMENTO DA MIOSINA VA INIBE O CRESCIMENTO DE TUMORES DE MELANOMA INDUZIDOS EM MODELO ANIMAL}

\author{
Antonio Carlos Borges \\ Orientadora: Profa. Dra. Enilza Maria Espreafico \\ Tese de apresentada em 27/01/2012
}

\begin{abstract}
A miosina Va é uma proteína motora envolvida no transporte e posicionamento de vesículas, organelas e mRNA. Além disso, postulou-se que a miosina-Va atua no seqüestro do fator pró-apoptótico, Bmf, no citoesqueleto de actina. Pesquisas realizadas em nosso laboratório demonstraram que um fragmento da miosina Va (MVaf), que corresponde ao sítio ligante de DLC2-Bmf, é capaz de induzir intensa apoptose em células de melanoma e de carcinoma in vitro. O presente trabalho teve por objetivo principal avaliar o potencial do MVaf como agente antitumoral, através de abordagens de terapia gênica em modelo animal. Foram geradas linhagens estabilizadas e com expressão controlada pelo sistema Tet-ON onde a expressão de EGFP ou EGFP-MVaf é induzida com a adição de doxiciclina. Essas linhagens foram testadas quanto à porcentagem de morte por apoptose e ativação de caspases. Tumores foram induzidos em camundongos C57BL/6 por inoculação subcutânea de células tumorigênicas positivas ou não para a expressão de EGFP-MVaf. Também foram utilizadas linhagens de fibroblasto embrionário murino selvagem (MEFs WT) e nocautes para os fatores Bim/Bmf e Bax/Bak

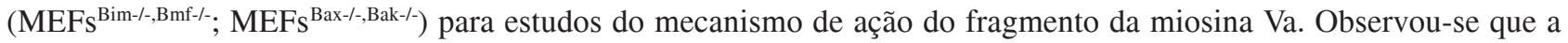
adição de butirato de sódio potencializa a expressão de EGFP-MVaf e, conseqüentemente, o efeito pró-apoptótico desse fragmento e que essas células são mais sensíveis aos quimioterápicos etoposídeo e taxol, apresentando maior susceptibilidade à apoptose. Verificou-se que a expressão de EGFP-MVaf em células de tumores de melanoma induzidos em camundongos C57BL/6J dificulta o crescimento desses tumores. Quanto ao estudo com MEFs, observou-se que células nocautes para os fatores pró-apoptóticos Bim/Bmf e Bax/Bak são menos susceptíveis à morte induzida pelo fragmento da miosina Va. Indução da expressão de MVaf desencadeia a liberação da proteína proapoptótica Smac (fusionada ao repórter fluorescente Cherry) do espaço intermembranas da mitocôndria para o citoplasma sugerindo que a morte apoptótica induzida por MVaf requer a permeabilização da membrana mitocondrial externa (MOMP). Concluindo, os dados apresentados aqui nos permitem propor o MVaf como uma molécula promissora para o desenvolvimento de novas abordagens terapêuticas contra o câncer.
\end{abstract}

\section{PROTEÔMICA FUNCIONAL: ESTUDO DO PAPEL DA NUCLEOFOSMINA NA GLIOMAGÊNESE}

\author{
Marcela Gimenez \\ Orientador: Prof. Dr. José César Rosa \\ Tese de Doutorado apresentada em 13/02/2012
}

Os gliomas somam mais de 70\% de neoplasias do sistema nervoso central. Gliomas de baixo grau apresentam uma tendência para progredir para fenótipos mais malignos sendo que os mais frequentes e agressivos compreendem os glioblastomas (GBM). Em estudos prévios, baseados em eletroforese bidimensional e espectrometria de massas, nós reportamos que a proteína nucleofosmina (NPM) estava aumentada em GBMs, quando comparados com tumores astrocíticos de graus II e III e tecido cerebral não neoplásico. NPM é uma fosfoproteína nucleolar relacionada à apoptose, biogênese dos ribossomos, mitose e reparo do DNA, que possui expressão alterada em câncer. Neste trabalho foram realizados estudos utilizando silenciamento gênico de NPM por RNA de interferência (siRNA) em células U87MG derivadas de GBM. Ensaios funcionais foram realizados para estudar o papel de NPM nas células transfectadas com siRNA-NPM. Os efeitos biológicos do silenciamento de NPM foram a diminuição de formação de colônias e a sensibilização para morte celular 
induzida pelo agente quimioterápico temozolomida. Com o objetivo de entender as alterações moleculares das células silenciadas, a análise proteômica foi realizada em células U87MG transfectadas com siRNA-NPM no $7^{\circ}$ dia, onde foi verificado a diminuição de até $80 \%$ no nível protéico e de RNA mensageiro de NPM. Extratos protéicos de células U87MG transfectadas siRNA-NPM, U87MG parental e U87MG tratada com oligonucleotídeos sem qualquer homologia (NTC) foram digeridos com tripsina. Os peptídeos foram marcados com iTRAQ, separados por cromatografia líquida e analisados por espectrometria de massas (ESI-Q-TOF-MS). Das proteínas identificadas como diferencialmente expressas, quatro estavam aumentadas nas células com NPM silenciada e 14 proteínas apresentaram expressão diminuída, em comparação com células controle. Análise por ontologia das proteínas identificadas revelou que 6 delas estão envolvidas na regulação da apoptose (ENPL_HUMAN, ITCH_HUMAN, 1433Z_HUMAN, GRP78_HUMAN, ACTN4_HUMAN, LMNA_HUMAN). Dentre elas, destacou-se a proteína GRP78 que apresentou uma expressão reduzida nas células silenciadas. GRP78 é uma proteína envolvida com resposta ao estresse no retículo endoplasmático, processos anti-apoptóticos e quimioresistência em câncer. Com o objetivo de estender os estudos de NPM na gliomagênese, foram realizados estudos proteômicos em amostras de tecidos comparando-se amostras obtidas de tecido cerebral não tumoral, astrocitoma grau II, GBM com curta ou sobrevida longa dos pacientes após diagnóstico, oligodendroglioma grau II e oligodendroglioma grau III. Foi utilizada marcação com iTRAQ para quantificação das proteínas que foram identificadas em espectrômetro de massas LTQ Orbitrap Velos. Um total de 1095 proteínas marcadas com iTRAQ foi identificado, das quais 268 apresentaram diferença de expressão maior ou menor que duas vezes, em pelo menos um grupo analisado, em relação ao grupo referência (tecido não-neoplásico). Algumas proteínas que apresentaram correlação com malignidade dos tumores foram selecionadas para validação por western blot, sendo elas HSPB1_HUMAN, GRP94_HUMAN, IDH1_HUMAN, NPM_HUMAN, RKIP_HUMAN, NUCL_HUMAN, NOVA1_HUMAN, ASAH_HUMAN e LGALS3BP_HUMAN. NPM foi encontrada aumentada em GBM e oligodendrogliomas, o que sugere uma participação importante dessa proteína no processo de tumorigênese. Outras proteínas, como HSPB1 foi detectada como aumentada em glioblastoma de sobrevida curta, sugerindo sua participação nesse fenótipo mais agressivo e de pior prognóstico. A proteína NOVA1 foi associada com GBMs e oligondrogliomas grau III. O conjunto dos resultados obtidos indicou uma participação de NPM na tumorigênese dos gliomas, sugerindo que NPM pode ser considerado um alvo para desenvolvimento de novas drogas para terapia em gliomas.

\title{
CARACTERIZAÇÃO DA PROTEÍNA LMSIR2RP3 E SEU POSSÍVEL ENVOLVIMENTO NO CONTROLE DA EXPRESSÃO GÊNICA NO PARASITA PROTOZOÁRIO Leishmania spp
}

\author{
Nilmar Silvio Moretti \\ Orientador: Prof. Dr. Luiz Ricardo Orsini Tosi \\ Tese de Doutorado apresentada em 30/03/2012
}

O estabelecimento de regiões de cromatina transcricionalmente ativas ou inativas é um processo crucial para a organização e expressão do genoma nos eucariotos superiores. Essa demarcação acontece pela limitação do acesso da maquinaria de transcrição ao DNA. Neste contexto modificações póstraducionais que acontecem nas histonas têm um papel central nesse fenômeno e consequentemente no controle da expressão gênica. No parasita protozoário Leishmania, o controle da expressão gênica ocorre principalmente no nível pós-transcricional. Para melhor entender os possíveis mecanismos epigenéticos neste parasita, nós iniciamos o estudo de um homólogo da proteína Sir2 de Saccharomyces cerevisae. A proteína Sir2 pertence a classe das histona deacetilases NAD+-dependentes (HDACs) e seu envolvimento com modificações pós-traducionais das histonas já foi extensivamente estudado em alguns eucariotos, assim como, seu envolvimento nos mecanismos de silenciamento gênico, reparo de DNA e envelhecimento. Em nosso trabalho verificamos que LmSir2 possui todos os resíduos necessários para sua atividade catalítica em sua estrutura e que ela é capaz de complementar uma linhagem de levedura mutante nulo para ScSir2 e restaurar o mecanismo de silenciamento telomérico. Utilizando uma versão fusionada da proteína nós verificamos que LmSir2 possui localização nuclear. Para investigar o efeito de silenciamento no parasita, nós geramos uma linhagem superexpressora de LmSir2 para análises de microarranjos. Nos experimentos verificamos que vários genes tiveram sua expressão alterada, incluindo genes relacionados com a regulação da transcrição, controle da tradução, modificação de cromatina e processamento de snoRNAs. Interessantemente, quando comparamos a posição desses genes com a localização de regiões de cromatina acetilada (H3ac) no genoma, encontramos uma grande porcentagem dos genes com sua expressão downregulada ocupando as mesmas posições das regiões de H3ac. Além disso, algumas dessas H3ac correspondem a SSR, que acredita-se sejam locais de início de transcrição em Leishmania. Utilizando protocolos específicos também demosntramos que a proteína LmSir2 é capaz de se associar com a cromatina desse parasita. Nossos dados sugerem um possível envolvimento da proteína LmSir2rp3 na regulação do estado de modificação da cromatina em Leishmania major e consequentemente o desempenho de algum papel no controle do início da transcrição. 


\title{
Bioquímica
}

\section{FITASE DE Aspergillus japonicus: ESTUDOS DE PRODUÇÃO EM BIORREATORES, CARACTERIZAÇÃ̃O, APLICAÇÃO EM RAÇÃO ANIMAL E EXPRESSÃO EM Pichia pastoris}

\author{
Alexandre Maller \\ Orientadora: Profa. Dra. Maria de Lourdes T. M. Polizeli \\ Tese de Doutorado apresentada em 28/02/2012
}

O fósforo é um importante nutriente para os sistemas biológicos, armazenado principalmente como ácido fítico pelas plantas, componente base de rações. As fitases hidrolisam este composto, liberando inositol e fosfato. Assim, estas enzimas possuem grande potencial biotecnológico para aplicação em ração animal. Os fungos possuem a capacidade de secretar uma variedade de enzimas para o meio extracelular, justificando sua utilização para obtenção de fitases. Os objetivos deste trabalho foram produzir, caracterizar e aplicar fitases em ração animal. O melhor procedimento para dosagem fitásica foi uma modificação da metodologia descrita por YIN et al. (2007). Dentre os fungos testados, Aspergillus japonicus apresentou maior produção, principalmente em meio Czapeck suplementado com farelo de trigo, incubado a $30^{\circ} \mathrm{C}, 100 \mathrm{rpm}$ por 72 horas. O fungo aumentou a produção em 2,5 vezes após otimização de cultivo através de Delineamento de Plackett-Burman e Delineamento Composto Central Rotacional, utilizando baixos níveis de extrato de levedura, $\mathrm{KH}_{2} \mathrm{PO}_{4}$ e $\mathrm{MgSO}_{4} \cdot 7 \mathrm{H}_{2} \mathrm{O}$. A enzima possui maior atividade à $50^{\circ} \mathrm{C}$ e pH 3,$5 ; 6,0$ e 7,5, com tempo de meia vida de 25 minutos nesta temperatura. A enzima foi semi-purificada através de técnicas cromatográficas utilizando colunas de troca-aniônica, gel filtração e afinidade de fosfato. No entanto, a baixa recuperação ao final do processo inviabilizou os experimentos de caracterização bioquímica. Antiespumante não afetou a produção da fitase selvagem de A. japonicus e o aumento de escala de cultivo de 25 para $500 \mathrm{~mL}$ apresentou um acréscimo de 24 vezes nos níveis de U totais. O fluxo de ar estabelecido para biorreatores foi de $0,1 \mathrm{vvm}$, onde a máxima produção enzimática ocorreu com 120 horas em condições próximas a neutralidade em STR e com 144 horas em condições ácidas em air-lift. Estas diferenças de pH não afetaram significativamente a forma ou tamanho dos pellets. $\mathrm{O}$ extrato enzimático não gerou citotoxicidade em células metabolicamente ativas, nem apresentou traços de aflatoxina B1, B2, G2 e G1, zearalenona ou ocratoxina. Os testes in vitro de adição em rações de frango de corte, poedeira, coelho e peixe, mostraram um excelente potencial do extrato em liberar tanto fosfato, quanto açúcares redutores em função do tempo. Os testes in vivo utilizando frangos de corte indicaram que o extrato enzimático foi capaz de suprir a deficiência de fosfato disponível nas formulações, apresentando um consumo de ração, ganho de peso e conversão alimentar semelhantes ao teste controle. Além disso, a porcentagem de fósforo presente na matéria mineral do fêmur e tíbia dos animais testados também foi estatisticamente igual ao experimento controle. O gene phyA, com $1341 \mathrm{pb}$, que codifica a fitase de A. japonicus, foi clonado no vetor pPIC9kf1- para transformar linhagens de Pichia pastoris GS115. A fermentação da levedura mutante em air-lift mostrou maior expressão de PhyA4 com 3\% de metanol. A enzima mutante apresentou temperatura ótima de $50^{\circ} \mathrm{C}$, tempo de meia vida de 40 minutos nesta temperatura, $\mathrm{pH}$ ótimo de 4 a 6,5, com atividade residual de $94 \%$, do pH 5,0 a 6,0, após 24 horas.

\section{CARACTERIZAÇÃO FUNCIONAL DOS CORPOS DE FBXO25 (FANDS)}

\author{
Adriana Oliveira Manfiolli \\ Orientador: Prof. Dr. Marcelo Damário Gomes \\ Tese de Doutorado apresentada em 16/03/2012
}

A proteína FBXO25, identificada in silico em 1999, é uma das 80 proteínas do tipo F-box (FBP) que atuam como fatores de especificidade para a família mais estudada de E3 ubiquitina-ligases humanas, as do tipo RING (Really Interesting New Gene-BoX 1) oligoméricas denominadas SCF1 - compostas por Skp1, Cullin1, RBX1 e uma FBP - que estão envolvidas na ubiquitinação de proteínas para degradação via Sistema Ubiquitina Proteassoma (SUP). A FBXO25 é capaz de formar um complexo SCF1 ativo e acumula-se no núcleo celular formando uma nova estrutura subnuclear denominada FANDs (FBXO25 Associated Nuclear Domains) que está associada à ubiquitinacão nuclear. Nesse trabalho, nós mostramos que os FANDs colocalizam com agregados de proteínas poliglutaminadas (PoliGlns) característicos de diversas desordens neurodegenerativas, como a doença de Huntington e diversas ataxias espinocerebelares. Interessantemente, a FBXO25 hiperexpressa recruta a huntintina e a ataxina-7 mutantes para os FANDs. Além disso, verificamos redução na agregação das proteínas PoliGlns quando o complexo $\mathrm{SCF} 1^{\mathrm{FBX} 025}$ é superexpresso e diminuição na toxicidade celular na presença da hiperexpressão da FBXO25. Assim, podemos concluir que a FBXO25 ajuda a proteger as células do acúmulo anormal e toxicidade ocasionados por proteínas PoliGlns. 


\title{
Clínica Cirúrgica
}

\section{AVALIAÇÃO DO TRATAMENTO POR DERIVAÇÃO LIQUÓRICA DA HIDROCEFALIA EXPERIMENTAL INDUZIDA EM RATOS}

\author{
Diego Augusto Leme Correa \\ Orientadora: Profa. Dra. Luiza da Silva Lopes \\ Dissertação de Mestrado apresentada em 03/02/2012
}

\begin{abstract}
A hidrocefalia é uma síndrome resultante do desbalanço entre a formação e a absorção do líquido cerebroespinal e consequente acúmulo do mesmo no interior dos ventrículos cerebrais Clinicamente, as crianças hidrocéfalas podem apresentar uma variada série de distúrbios neurológicos, nem sempre revertidos com o tratamento, mesmo após o desenvolvimento de mais e mais sofisticados sistemas de derivação liquórica. Aprofundados estudos são necessários, com o intuito de se estabelecer as alterações que são reversíveis com o alívio ou restabelecimento do sistema de circulação liquórica, e o estágio de evolução da hidrocefalia em que a recuperação funcional do tecido nervoso é ainda possível. O objetivo deste trabalho foi desenvolver um sistema de derivação liquórica para ratos hidrocefálicos, e estudar as lesões ao encéfalo revertidas com o tratamento. Foram usados ratos lactentes submetidos à hidrocefalia pela injeção intracisternal de caulim aos 7 dias de vida. Após constatação da ventriculomegalia por ressonância magnética, parte dos animais era submetida à derivação ventrículo-subcutânea. Os animais foram pesados diariamente, submetidos a testes de comportamento e a uma segunda ressonância magnética de encéfalo ao final do experimento (14 dias de hidrocefalia). A seguir, foram sacrificados e seus encéfalos foram processados para avaliação histopatológica, incluindo a avaliação da mielinização pela coloração por solocromo-cianina. Nos grupos controle $(\mathrm{C})$, hidrocefalia $(\mathrm{H})$, derivados ventrículo-subcutâneo funcionante (DVSF) e os derivados ventrículo-subcutâneo não funcionante (DVSNF), os testes de comportamento e o ganho ponderal foram bons indicativos do avanço da ventriculomegalia, sendo que quanto piores o desempenho e o ganho ponderal, maior o tamanho ventricular. Os testes de comportamento e o ganho ponderal mostraram-se comprometidos pela hidrocefalia e melhoraram com o tratamento com derivação liquórica. A transferência de magnetização na ressonância magnética forneceu informações sobre a gravidade da hidrocefalia, bem como do sucesso do tratamento por derivação liquórica. A avaliação histológica pelo método histoquímico por solocromo-cianina reforçou a idéia de que a hidrocefalia prejudica a mielinização das estruturas periventriculares e o tratamento com derivação liquórica ajuda a recuperar o processo de mielinização.
\end{abstract}

\section{Clínica Médica}

\section{MODIFICAÇÕES TECIDUAIS E MECANISMOS DE AÇÃO DA FRAÇÃO F1 DO LÁTEX DA SERINGUEIRA Hevea brasiliensis NA CICATRIZAÇÃO DE ÚLCERAS CUTÂNEAS EM RATOS DIABÉTICOS}

\author{
Thiago Antonio Moretti de Andrade \\ Orientador: Prof. Dr. Marco Andrey Cipriane Frade \\ Tese de Doutorado apresentada em 03/02/2012
}

O diabetes, relacionado ao estresse celular, altera consideravelmente a cicatrização de úlceras cutâneas. O látex da seringueira Hevea brasiliensis tem se apresentado como importante indutor da cicatrização especialmente nas ulcerações comprometidas pelo diabetes no qual foi observado clinicamente estímulo do látex à total reepitelização. Foram avaliadas as modificações teciduais e os mecanismos de ação da fração proteica (F1) do látex na cicatrização de úlceras cutâneas em ratos diabéticos e não diabéticos. Inicialmente, foi testada a citotoxicidade da F1 em culturas de fibroblastos NIH-3T3 e queratinócitos humanos pelo método MTT. Em seguida, foram utilizados 80 ratos Wistar, dos quais 40 foram induzidos ao 
diabetes (DM) (por streptozotocina $45 \mathrm{mg} / \mathrm{Kg}$ ) e 40 não-diabéticos $(\mathrm{N})$, submetidos a úlceras dorsais por punch $(1,5 \mathrm{~cm}$ de diâmetro), as quais foram tratadas com gel de carboximetil-celulose (CMC) 4\% (DM/N-sham) e CMC+F1 0,01\% (DM/N-F1), seguidos por 2, 7, 14 e 21 dias após a lesão. Após eutanasiados 10 animais/tempo/grupo, biópsias da pele/ úlcera/cicatriz foram coletadas para estudo da reepitelização pelo cálculo do índice de cicatrização; histomorfometria (HE e Gomori) para quantificação de infiltrado inflamatório, vasos, fibroblastos e \% da área de colágeno; imunoistoquímica para OSM, OSMR- $\beta$, iNOS, VEGF, eNOS, TGF- $\beta 1$, IGF, e sinalizadores da insulina: IRS, AKT, SHC e ERK; dosagem do estresse oxidativo (NO-óxido nítrico, LPM-lipoperóxidos de membranas, MPO-mieloperoxidase, MDA-malondialdeído, FOX- $\mathrm{H}_{2} \mathrm{O}_{2} \mathrm{e}$ defesas antioxidantes: GSH-glutationa e TRAP-Capacidade Antioxidante Total e citometria de fluxo para CD11b ${ }^{+}, \mathrm{CD}^{+} \mathrm{e}$ $\mathrm{CD} 8^{+}$. A fração F1 apresentou-se atóxica em relação às culturas de fibroblastos NHI-3T3 e queratinócitos humanos. Além disso, a pele diabética (sem tratamento) apresentou maior quantidade de infiltrado inflamatório ( $\mathrm{p}=0,0001)$ e estresse oxidativo [NO ( $\mathrm{p}=0,0473$ ) e LPM ( $\mathrm{p}=0,0001)$ ] que a não diabética. No entanto, o DM diminuiu na pele os níveis de angiogênese $(\mathrm{p}=0,0001), \operatorname{VEGF}(\mathrm{p}=0,0002)$ e eNOS $(\mathrm{p}=0,0206)$ bem como a sinalização da insulina (IRS- $\mathrm{p}=0,0001$, AKT- $\mathrm{p}=0,0041$, SHC$\mathrm{p}=0,0006$, ERK-p=0,0002) em relação dos não diabéticos. Quando a proteína F1 foi utilizada no tratamento das úlceras dos ratos diabéticos, houve importante quimiotaxia de células inflamatórias para a úlcera até $\mathrm{o} 7^{\circ} \mathrm{dia}(\mathrm{p}=0,0452)$, especialmente PMN, com maior estresse oxidativo [OSM, OSMR-?, iNOS, NO, MPO, FOX e LPM (p=0,0001)], além de assemelhar-se à cicatrização normal (grupo $\mathrm{N}$ sham). Este estímulo à fase inflamatória e ao estresse oxidativo pareceu favorecer as próximas fases da cicatrização, aumentando a angiogênese, VEGF e eNOS no $14^{\circ}$ e $21^{\circ}$ dia, o que certamente favoreceu a reepitelização ( $\mathrm{p}=0,0026)$. Os efeitos da associação $\mathrm{F} 1$ x DM também pareceu estimular a fibroplasia no $14^{\circ}$ e $21^{\circ} \mathrm{dia}(\mathrm{p}=0,0121)$ e colagênese $(\mathrm{p}=0,0001)$. Além disso, F1 associada ao DM permitiu maior expressão de IRS, SHC e ERK diferente do DM sham e também semelhante ao $\mathrm{N}$ sham. Sendo assim, o maior recrutamento de células inflamatórias, estímulo à produção de citocinas e fatores de crescimento, o estresse oxidativo desencadeado até o $14^{\circ}$ dia, o importante estímulo à fibroplasia e colagênese bem como a importante ativação da sinalização da insulina, outrora diminuída nos diabéticos, foram fatores essenciais que permitiram a total reepitelização das úlceras cutâneas tratadas com F1 nos ratos diabéticos.

\title{
ANÁLISE IN VIVO E in vitro DA FORMA TRUNCADA DNP73 NA LEUCEMIA PROMIELOCÍTICA AGUDA
}

\author{
Antonio Roberto Lucena deAraujo \\ Orientador: Prof. Dr. Eduardo Magalhães Rego \\ Tese de Doutorado apresentada em 17/02/2012
}

O $\triangle N p 73$ é uma isoforma truncada do gene TP73 e atua como um potente inibidor da atividade transcripcional das proteínas TP53 e TAp73, desempenhando, desta forma, um importatne papel na proliferação e morte celular. Na verdade, o que determina a atividade oncogênica do gene TP73 é um balanço entre suas isoformas transcricionalmente ativa (TAp73) e inativa $(\Delta \mathrm{Np} 73)$, e essa relação correlaciona-se com o prognóstico clínico e falha no tratamento em diversas neoplasias humanas, incluindo leucemia mielóide aguda (LMA). Nosso grupo relatou que na LMA, uma maior relação de expressão $\Delta \mathrm{N} p 73 / \mathrm{TA} p 73$ está associada com leucemias de pior prognóstico e resistência à apoptose induzida citarabina. Na leucemia promielocítica aguda (LPA), ambas as formas são expressas, mas seu significado clínico ainda é desconhecido. Desta forma, o presente trabalho teve como objetivo determinar se relação da expressão gência $\Delta$ N $p 73 / \mathrm{TA} p 73$ está associada com o prognóstico de pacientes com LPA e investigar os mecanismos pelos quais o $\Delta \mathrm{Np} 73$ pode conferir a uma célula PML-RARa+ vantagem proliferativa. Usando sondas isoforma-específicas para as variantes TAp 73 e $\Delta N p 73$, a análise da expressão gênica foi realizada em 223 amostras de pacientes com LPA por reação em cadeia da polimerase quantitativa. Os pacientes foram divididos em tercis e suas características clínicas e laboratoriais foram então comparadas. Foi observado que os pacientes alocados no $3^{\circ}$ tercil (pacientes que apresentaram uma alta relação de $\Delta$ Np73/TAp73) apresentaram uma maior contagem de leucócitos no sangue periférico ao diagnóstico $(\mathrm{p}<0,001)$, bem como uma maior frequência de mutação do tipo ITD no gene FLT3 ( $\mathrm{p}=0,001)$. Além disso, a maioria dos casos de pacientes com alto risco de recidiva apresentaram altos níveis de expressão $\Delta$ Np73/TAp73 (risco relativo [RR]: 2,36, IC95\%: 1,7-3,28). Os resultados de desfechos clínicos foram obtidos em 131 pacientes inceridos nos protocolos de tratamento APL99 $(n=41)$ e IC-APL $(n=90)$. O tempo médio de seguimento desses pacientes foi de 29 meses, variando de 1 a 85 meses, com estimativa de sobrevida em cinco anos de 
78\%. A sobrevida global (SG) média de todos os pacientes foi de 67 meses [IC95\%; 61-73], enquanto que a SG foi de 67 meses [56 to 78] para os pacientes alocados no tercil inferior e 42 meses [32 to 51] para aqueles alocados no tercil superior $(\mathrm{p}=0.014)$. Análise univariada identificou contagem de leucócitos ao diagnóstico ( $\mathrm{p}=0,016)$, alta relação $\Delta$ Np73/TAp73 $(\mathrm{p}=0,014)$ e presença de mutação do gene FLT3 ( $\mathrm{p}=0,011)$ como fatores preditivos de baixa SG. Entretanto, na análise multivariada de Cox, esses três fatores não foram independentes. Até abril de 2011, um total de oito recaídas (6\%) foram registradas. A taxa de sobrevida livre de doença (SLD) em cinco anos foi de 88\% e a SLD média foi de 76 meses [71,2-80,9]. SLD foi significativamente menor nos pacientes do $3^{\circ}$ tercil comparados com pacientes do $2^{\circ}$ e $1^{\circ}$ tercis $(72 \%$ vs $97 \%$ vs $100 \%$, respectivamente, $\mathrm{p}<0,001)$. Para testar a significância funcional da associação entre a oncoproteína PML-RARa com a hiperexpressão do gene $\Delta \mathrm{Np} 73$, células da medula óssea de camundongos transgênicos hCG-PML-RARa foram transfectadas com o vetor retroviral MSCV carregando o cDNA do gene $\Delta$ Np73 (PML-pMIG- $\Delta$ N). Expressão do $\Delta$ Np73 em células PML-RARa+ aumentou da taxa de proliferação celular em 2,5 vezes em comparação com PML-RARa+ transfectadas com o vetor vazio $(\mathrm{p}=0,03)$. Este aumento foi resultado de acúmulo de células na fase G2/M (5,8 $\pm 0,08 \%$ para PMLpMIG vs 9,8 $\pm 0,3 \%$ para PML-pMIG- $\Delta \mathrm{N}, \mathrm{p}<0,001)$, bem como na fase $S$ do ciclo celular $(27,7 \pm 0,9 \%$ para PML-pMIG vs $36,8 \pm 0,8 \%$ para PML-pMIG- $\Delta \mathrm{N}, \mathrm{p}=0,001)$. Além disso, a transfecção do $\Delta \mathrm{Np} 73$ resultou em resistência à apoptose induzida por citarabina. Após $24 \mathrm{~h}$ de cultura com $100 \mu \mathrm{g} / \mathrm{ml}$ de citarabina (dose efetiva-50\%), o efeito fracionário para a droga (\% anexina-V+ (células tratadas - não tratadas)/100 - \% anexina-V+ em células não tratadas) foi de 32,1\% para PMLpMIG- $\Delta$ N e 54,8\% para PML-pMIG (p<0,001). Em conclusão, o aumento de expressão relativa do gene $\Delta$ Np73 está associado com uma menor SG e SLD em pacientes com LPA, o que parece ser reflexo de um aumento da proliferação celular e resistência à apoptose induzida por este gene.

\title{
EPIDEMIOLOGIA DA MORTE SÚBITA CARDÍACA NO MUNICÍPIO DE RIBEIRÃO PRETO: ANÁLISE ATRAVÉS DOS CASOS ENCAMINHADOS AO SERVIÇO DE VERIFICAÇÃO DE ÓBITOS
}

\author{
Maria Fernanda Braggion \\ Orientador: Prof. Dr. André Schmidt \\ Dissertação de Mestrado apresentada em 19/03/2012
}

A morte súbita cardíaca (MSC) é definida como aquela que ocorre de maneira inesperada, de origem cardiovascular, dentro de uma hora do início dos sintomas em um indivíduo sem condição clínica prévia potencialmente fatal ou em indivíduo que foi visto sem qualquer sintoma 24 horas antes do óbito. Trata-se de um evento relativamente frequente. Do ponto de vista epidemiológico, registros americanos indicam que entre 184000 a 400000 eventos ocorrem anualmente. Existem poucos dados confiáveis na literatura nacional que possam ser comparados aos existentes nos países do hemisfério norte.

A cidade de Ribeirão Preto possui o Serviço de Verificação de Óbitos (SVO) sob a tutela da Faculdade de Medicina de Ribeirão Preto da Universidade de São Paulo, para onde podem ser encaminhados os casos de morte súbita, para avaliação diagnóstica e determinação da causa mortis. O objetivo deste estudo foi caracterizar a prevalência de MSC no município de Ribeirão Preto com base nos registros obtidos no SVO, ao longo de 5 anos, de forma retrospectiva.

Foram analisados 4501 laudos de necropsias realizadas pelo SVO entre 2006 e 2010, tendo sido identificados e caracterizados 899 casos de morte súbita cardíaca neste período (20\%). A maior parte dos casos ocorreu por infarto agudo do miocárdio $(63,9 \%)$ em homens $(66,6 \%)$ entre a quinta e sétima décadas de vida. Os óbitos ocorreram em sua maioria no domicílio (53,3\%) ou em Unidades Básicas de Saúde ou Hospitais, locais em que os pacientes, em sua maioria, chegaram em parada cardiorrespiratória (37,8\%). Entre as comorbidades encontradas, a mais prevalente foi hipertensão arterial sistêmica (57,3\%). A doença de Chagas foi constatada em cerca de 5,5\% dos indivíduos.

Apesar de ser uma entidade reconhecida na Classificação Internacional de Doenças (CID-10) pelo código I46-1, somente em 2,2\% dos laudos definitivos emitidos pelo patologista responsável, este diagnóstico foi designado como causa mortis e em cerca de $2,9 \%$ dos casos os órgãos foram submetidos a análise microscópica.

Através deste estudo, concluímos que a morte súbita é um importante problema de saúde, a medida que acomete um grande número de indivíduos com desfecho fatal. É importante conscientizar a população a respeito dos fatores de risco associados e sintomas que podem preceder o evento, na tentativa de evitá-lo. A criação de protocolos para a realização de necropsias em casos de morte súbita é importante pois a elucidação da causa mortis contribui para a criação de medidas preventivas. 


\title{
Farmacologia
}

\section{INTERAÇÃO ENTRE OS SISTEMAS ENDOCANABINÓIDE E ENDOVANILÓIDE LOCALIZADOS NO CÓRTEX PRÉ-FRONTAL MEDIAL PRÉ-LÍMBICO DE RATOS NA MODULAÇÃO DE RESPOSTAS EMOCIONAIS}

\author{
Manoela Viar Fogaça \\ Orientador: Prof. Dr. Francisco Silveira Guimarães \\ Dissertação de Mestrado apresentada em 24/01/2012
}

Os agonistas de receptores canabinóides (CB1) geralmente produzem efeitos bifásicos de forma dose-dependente nas respostas de ansiedade. Baixas doses induzem efeito do tipo ansiolítico, enquanto que doses maiores são inefetivas ou induzem efeito do tipo ansiogênico, provavelmente devido à ativação de Receptores de Potencial Transitório Vanilóide Tipo 1 (TRPV1). Neste trabalho, esta hipótese foi investigada verificando-se os efeitos do agonista de receptores CB1/ TRPV1, ACEA, injetado no córtex pré-frontal medial pré-límbico (PL) de ratos e a participação dos endocanabinóides (ECs) nos efeitos do tipo ansiolítico induzido pelo antagonismo de receptores TRPV1. Para isso foram utilizados o modelo do labirinto em cruz elevado (LCE) e o lamber punido de Vogel (LPV). Além disso, a expressão de receptores CB1 e TRPV1 no PL foi verificada por meio de imunofluorescência. O ACEA induziu efeito do tipo ansiolítico na dose intermediária, o qual foi atenuado pela administração prévia do antagonista de receptores CB1, AM251. A dose alta e inefetiva de ACEA não produziu efeito. Entretanto, induziu efeito do tipo ansiogênico ou ansiolítico após injeção prévia de AM251 ou o antagonista de receptores TRPV1, 6-iodonordihidrocapsaicina (6-I-CPS), respectivamente. Uma dose maior de 6-I-CPS induziu efeito do tipo ansiolítico tanto no EPM quanto no LPV, o qual foi prevenido por meio de injeção prévia de AM251. O ensaio de imunofluorescência demonstrou que os receptores CB1 e TRPV1 estão localizados em neurônios próximos no PL. Os resultados do presente trabalho sugerem que os sistemas endocanabinóide e endovanilóide interagem no PL no controle de comportamentos de ansiedade.

\section{O SISTEMA COLINÉRGICO PRESENTE NO CÓRTEX PRÉ-FRONTAL MEDIAL MODULA A EXPRESSÃO DO MEDO CONDICIONADO AO CONTEXTO VIA RECEPTORES MUSCARÍNICOS $\mathrm{M}_{3}$}

\author{
Alessandra das Graças Fedoce \\ Orientador: Prof. Dr. Leonardo Resstel Barbosa Moraes \\ Dissertação de Mestrado apresentada em 25/01/2012
}

O córtex pré-frontal medial (CPFM) é uma importante estrutura do sistema límbico envolvida na modulação do sistema nervoso autonômico e de respostas defensivas. Durante situações aversivas pode se observar tanto alterações nas respostas autonômicas (aumento da pressão arterial, frequência cardíaca e queda da temperatura cutânea) quanto nas comportamentais (aumento no tempo de congelamento). Em particular, o CPFM está envolvido com a expressão da resposta emocional condicionada (REC) que é caracterizada pelas respostas autonômicas e comportamentais que são observadas durante o modelo do medo condicionado ao contexto (MCC). Finalmente, é possível observar uma elevação nos níveis de acetilcolina no CPFM durante o MCC. O presente trabalho investigou o envolvimento do sistema colinérgico presente no CPFM na expressão REC de ratos re-expostos ao contexto aversivo. Foi observado que a microinjeção bilateral do inibidor da recaptação de colina o hemicolínio (1 nmol / $200 \mathrm{~nL})$ ou de um antagonista de receptores muscarínicos a atropina $(0,06$ e $6 \mathrm{nmol} / 200 \mathrm{~nL})$ foram capazes de atenuar a REC. Além disso, o antagonista de receptor muscarínico $\mathrm{M}_{1}$ e $\mathrm{M}_{3}$, o fumarate $(6 \mathrm{nmol} / 200 \mathrm{~nL})$ e o antagonista de receptor muscarínico seletivo $\mathrm{M}_{1}$, a pirenzepina $(6 \mathrm{nmol} / 200 \mathrm{~nL})$ também reduziram a REC. Entretanto, na dose de $0,06 \mathrm{nmol}$ apenas a microinjeção de fumarate, mas não a pirenzepina, foi capaz de atenuar a REC, sugerindo que o efeito observado com a dose de $6 \mathrm{nmol}$ de pirenzepina pode ser sobre receptores $\mathrm{M}_{3}$. Por fim, o aumento dos níveis locais de acetilcolina no CPFM provocados pelo o inibidor da enzima acetilcolinesterase a neostigmina $(0,1 \mathrm{e} 1 \mathrm{nmol} / 200 \mathrm{~nL})$ foi capaz de aumentar a REC. Esses efeitos da neostigmina, foram inibidos pela administração local no CPFM de uma dose inefetiva de fumarate $(0,06 \mathrm{nmol})$, mas não de pirenzepina $(0,06 \mathrm{nmol})$ mostrando mais uma vez que a modulação da REC deve-se a ação de acetilcolina sobre receptores muscarínicos $\mathrm{M}_{3}$. Dessa maneira, nossos achados revelam que a neurotransmissão colinérgica presente no CPFM através da ativação de receptores muscarínicos $\mathrm{M}_{3}$ é importante na expressão de respostas comportamentais e autonômicas associadas à expressão do medo condicionado ao contexto. 


\title{
ENVOLVIMENTO DOS SISTEMAS GLUTAMATÉRGICO, NITRÉRGICO E DA VIA GMPC NO HIPOCAMPO DORSAL NA EXPRESSÃO DA RESPOSTA EMOCIONAL CONDICIONADA EM RATOS SUBMETIDOS AO MODELO DO MEDO CONDICIONADO CONTEXTUAL
}

\author{
Denise Fabri Rezende de Souza \\ Orientador: Prof. Dr. Leonardo Resstel Barbosa Moraes \\ Dissertação de Mestrado apresentada em 27/01/2012
}

A porção dorsal do hipocampo tem sido relacionada com a modulação da resposta emocional condicionada. Adicionalmente, trabalhos mostram uma elevação nos níveis de glutamato no hipocampo dorsal durante a exposição do animal a situações aversivas. Além disso, a interação N-Metil-D-Aspartato (NMDA) / óxido nítrico (NO) no hipocampo dorsal parecer ser importante nessas situações aversivas. Há também dados mostrando o papel da via guanosina monofosfato cíclica (GMPc) no hipocampo dorsal na modulação da ansiedade, confirmando o importante envolvimento dessa via. Entretanto, a função da interação receptor NMDA/ NO, via GMPc na expressão do medo condicionado ao contexto ainda não está completamente elucidada. Assim, este estudo investigou o possível envolvimento do receptor NMDA, do NO, bem como do GMPc na modulação da resposta emocional condicionada. Ratos Wistar foram submetidos às sessões de condicionamento aversivo ao contexto, sendo que os animais foram divididos nos seguintes grupos: condicionado (submetidos a choque nas patas) e não condicionado (não submetidos a choque nas patas). Quarenta e oito horas após a sessão de condicionamento, os animais foram re-expostos ao contexto aversivo e as respostas autonômicas (aumento de pressão arterial e freqüência cardíaca e queda da temperatura cutânea) e comportamental (congelamento) foram avaliadas. A administração intra-hipocampal de antagonista de receptores NMDA, o DL-AP7 (1 e $10 \mathrm{nmol} / 500 \mathrm{~nL}), 10$ minutos antes da re-exposição do animal ao contexto aversivo atenuou, em sua maior dose, a resposta emocional condicionada, enquanto a injeção de antagonista de receptor não-NMDA, o NBQX (10 nmol/500nL) não causou efeito sobre a resposta emocional condicionada. Outro grupo de animais foi sacrificado imediatamente após re-exposição ao contexto aversivo e teve o hipocampo dorsal retirado para detecção de nitrito e nitrato, formas estáveis do NO. De acordo com os resultados, a exposição do animal ao contexto aversivo promoveu um aumento das concentrações de nitrito e nitrato na área. Partindo desse resultado, foi administrado no hipocampo dorsal um inibidor da isoforma que sintetiza o NO, o $\mathrm{N}^{\omega_{-}}$ propil-L-arginina (N-propil) $(0,01$ e $0,1 \mathrm{nmol} / 500 \mathrm{~nL})$ ou um seqüestrador de NO, o carboxi-PTIO (S)-3-Carboxi-4hidroxifenilglicine (c-PTIO) $(0,2$ e $2 \mathrm{nmol} / 500 \mathrm{~nL})$. Tanto a inibição da nNOS quanto o seqüestro do NO reduziram a resposta emocional condicionada. Além disso, a administração de inibidor da guanilato ciclase, o ODQ $(0,1 \mathrm{e} 1 \mathrm{nmol} / 500 \mathrm{~nL})$ no hipocampo dorsal também foi capaz de reduzir a resposta emocional condicionada. Esses resultados indicam que os sistemas glutamatérgico e nitrérgico modulam a expressão do medo condicionado ao contexto, possivelmente através da via receptores NMDA/ NO e que, ainda, essa interação envolve a síntese de GMPc.

\section{PAPEL DA IL-10 E DO IFN-GAMA NA MOVIMENTAÇÃO ORTODÔNTICA EM CAMUNDONGOS}

\author{
Thiago Pompermaier Garlet \\ Orientador: Prof. Dr. Fernando de Queiroz Cunha \\ Tese de doutorado apresentada em 02/02/2012
}

A terapia ortodôntica consiste na aplicação de forças mecânicas de maneira planejada às estruturas dentais, levando o periodonto a responder seguindo padrões definidos, e finalmente resultando em uma remodelação controlada deste tecido e no deslocamento dos dentes. Esta prática vem sendo realizada na clínica com sucesso há um longe tempo, mas apenas recentemente os mecanismos fisiológicos envolvidos começaram a ser elucidados. Mediadores inflamatórios têm sido descritos como participantes no processo, e dentre estes a citocina modulatória IL-10 e o fator pró-inflamatório IFN- $\gamma$ são considerados importantes. Um entendimento mais profundo da resposta do periodonto e de sua remodelação pode levar a avanços clínicos importantes. Com o objetivo de investigar este fenômeno, neste trabalho desenvolvemos um modelo murino de movimentação ortodôntica, e comparamos animais da linhagem C57BL/6 WT, a animais deficientes de IL-10 (IL-10 KO) e animais deficientes de IFN- $\gamma$ (IFN- $\gamma$ KO), geneticamente modificados. O dispositivo ortodôntico é composto por uma mola aberta de NiTi, instalada entre os incisivos e o primeiro molar superior, capaz de movimentar este molar em direção mesial. O movimento foi mensurado após 24 e 72h, e amostras dos sítios de pressão e tensão foram coletadas separadamente para análises de PCR. Nossos resultados apontam acentuação do movimento dentário nos animais IL-10 KO, relacionado a remodelação tecidual rápida e intensa. Além disso, animais IL-10 KO exibiram maior expressão de citocinas pró-inflamatórias, especialmente nos sítios de pressão, levando a maior produção de RANKL. 
Animais IFN- $\gamma$ KO apresentaram mudanças menos marcantes, como a modulação de alguns diferentes fatores mas produzindo resultados finais semelhantes. Em conjunto, estes dados sugerem que a IL-10 é um importante regulador da remodelação óssea por forças ortodônticas, e que IFN- $\gamma$ executa um papel menos decisivo.

\title{
ENVOLVIMENTO DA NEUROTRANSMISSÃO OPIOIDE NA VIA RECÍPROCA ENTRE A SUBSTÂNCIA CINZENTA PERIAQUEDUTAL E O COLÍCULO INFERIOR NA MODULAÇÃO DOS COMPORTAMENTOS DEFENSIVOS ASSOCIADOS AO PÂNICO
}

\author{
André Twardowschy \\ Orientador: Prof. Dr. Norberto Cysne Coimbra \\ Tese de Doutorado apresentada em 09/02/2012
}

Os comportamentos defensivos de animais de laboratório constituem um significante modelo para o entendimento de transtornos emocionais humanos. A microinjeção de antagonista de receptores GABA-A (bicuculina) ou a estimulação do teto mesencefálico com correntes elétricas de intensidade crescente, em ratos, provoca respostas defensivas associadas ao pânico. Alguns estudos convergentes têm demonstrado a existência de uma complexa interação entre conexões mediadas por peptídeos opioides endógenos e vias neurais mediadas por GABA. Tem sido proposto que os neurônios opioides exercem uma influência sobre os interneurônios GABAérgicos, os quais, por sua vez, exercem um controle inibitório tônico sobre as vias neurais mesencefálicas excitatórias. Assim, em nível mesencefálico, os peptídeos opioides podem atuar na desinibição ou inibição dos neurônios tonicamente inibidos pelo GABA, contribuindo, portanto, para a expressão dos comportamentos defensivos. No presente trabalho, utilizaram-se técnicas de estimulação elétrica ou química (com administração central de bicuculina) do colículo inferior (CI) e da coluna dorsal da substância cinzenta periaquedutal (SCPd) com o objetivo de avaliar o efeito da microinjeção de agonistas e antagonistas opioides por via intracolicular ou intra-SCPd, sendo sempre a estimulação feita em uma das estruturas mesencefálica abordadas, e o tratamento feito em outra reciprocamente conectada àquela. Também foi verificado o efeito da lesão neurotóxica nessas estruturas sobre os comportamentos defensivos eliciados pelo bloqueio GABAérgico local. Os presentes achados mostraram que houve uma redução das respostas defensivas eliciados tanto no CI como na SCPd, quando a estrutura oposta estudada foi lesada. Com relação às drogas opioides, os resultados obtidos mostraram que tanto os agonistas de receptores opioides do tipo $\mu$, microinjetados no CI ou na SCPd, foram capazes de reduzir as respostas defensivas induzidas pelo estímulo elétrico da SCPd ou do CI, e vice-versa. O pré-tratamento da SCPd ou do CI com antagonistas de receptores opioides do tipo $\mu$ e $\mathrm{\kappa}$ e com os agonistas do tipo $\mu$, foi capaz de reduzir os comportamentos defensivos induzidos pelo bloqueio GABAérgico no teto mesencefálico. No entanto, o agonista $\mathrm{\kappa}$ microinjetado na SCPd aumentou algumas respostas defensivas associadas ao pânico eliciadas pelo estímulo químico no CI. Em suma, os presentes resultados mostraram que tanto os agonistas como antagonistas de receptores opioides do tipo $\mu$ (nas doses aqui utilizadas) são capazes de reduzir os comportamentos defensivos associados ao pânico, e que o agonista de receptores $\kappa$ (na dose aqui utilizada) foi capaz de aumentar esses comportamentos defensivos.

\section{CONSEQUÊNCIAS DA HIPERHOMOCISTEINEMIA SOBRE A RESPOSTA À ENDOTELINA-1 E FENILEFRINA EM CORPO CAVERNOSO DE RATOS}

\author{
Hariane Côco \\ Orientadora: Profa.Dra. Ana Maria de Oliveira \\ Dissertação de Mestrado apresentada em 13/02/2012
}

A hiperhomocisteinemia (HHcy) tem sido associada à disfunção endotelial, em decorrência do aumento de ânion superóxido $\left(\mathrm{O}_{2}^{-}\right)$e redução da biodisponibilidade de óxido nítrico (NO), fatos estes que poderiam acarretar disfunção erétil. O objetivo deste trabalho foi estudar as consequências da HHcy sobre as respostas à endotelina-1 (ET-1) e fenilefrina $(\mathrm{PhE})$ em corpos cavernosos de ratos, bem como os mecanismos envolvidos. Os animais foram divididos em dois grupos, os quais receberam água (controle) ou DL-homocisteina tiolactona (DL-HcyT, grupo HHcy), na dose de $1 \mathrm{~g} / \mathrm{Kg} / \mathrm{dia}$, via oral por 15 dias. Análises morfológicas, de colágeno e expressão de $\alpha$-actina não revelaram macroalterações na estrutura de corpos cavernosos de ratos HHcy, sugerindo que alterações na funcionalidade destes tecidos não decorrem de modificações estruturais. A HHcy acarretou aumento dos níveis de $\mathrm{O}_{2}^{-}$em corpos cavernosos de ratos, avaliados por microscopia confocal. A reatividade vascular foi avaliada para KCl, nitroprussiato de sódio (NPS), acetilcolina (ACh), ET- 
1, IRL-1620 e PhE. Não foram observadas alterações na reatividade vascular para KCl ou NPS. O relaxamento induzido por ACh foi reduzido em corpos cavernosos de ratos HHcy. A contração induzida por ET-1, via receptores ETA, mostrou-se aumentada em corpos cavernosos de ratos HHcy, sugerindo possível envolvimento de $\mathrm{O}_{2}^{-}$basais em vias intracelulares, decorrentes da ativação de receptores ETA. Observou-se prejuízo do relaxamento induzido por ET-1 e IRL-1620 em corpos cavernosos de ratos HHcy, por ativação de receptores $\mathrm{ET}_{\mathrm{B}}$. O prejuízo do relaxamento induzido por IRL-1620 foi decorrente da produção e/ou biodisponibilidade reduzida de NO. A expressão de RNAm para pré-pró-ET-1, enzima conversora de ET1 e receptores ETA e ETB não foram alteradas em decorrência da HHcy. O Emax da PhE foi aumentado em corpos cavernosos de ratos HHcy, em decorrência de aumento nos níveis basais de $\mathrm{O}_{2}^{-}$e redução de fatores moduladores negativos da contração, tal como peróxido de hidrogênio $\left(\mathrm{H}_{2} \mathrm{O}_{2}\right)$, sugerindo possível prejuízo da enzima superóxido dismutase. A participação de metabólitos derivados da isoformas da enzima óxido nítrico sintase (NOS), eNOS, nNOS e iNOS que modulam negativamente a contração da PhE, mostraram-se importantes nesta resposta. Na HHcy, os metabólitos derivados principalmente da iNOS estão prejudicados, possivelmente por redução da atividade da NOS, processo de desacoplamento e/ou redução da biodisponibilidade de NO por interação com espécies reativas de oxigênio (ERO), formando peróxinitrito. A expressão de nitrotirosina, indicador da presença de peroxinitrito, não foi alterada em corpos cavernosos de ratos HHcy. As dosagens plasmáticas de nitrato mostraram redução dos níveis de NO em ratos HHcy, sendo sugestivo de redução de sua biodisponibilidade. A HHcy não alterou a expressão de RNAm para eNOS, nNOS e iNOS em corpos cavernosos de ratos. Os metabólitos da enzima cicloxigenase-1 (COX-1) e COX-2 participam modulando negativamente a contração da PhE e a HHcy não alterou esta modulação. Concluindo, a HHcy intermediária, por sua capacidade de aumentar os níveis basais de $\mathrm{O}_{2}^{-}$, pode afetar a função vasoativa, contração e relaxamento, do peptídeo ET1, bem como aumentar a resposta de contração à $\mathrm{PhE}$ em decorrência de prejuízo de $\mathrm{H}_{2} \mathrm{O}_{2}$ e redução de metabólitos derivados da iNOS em corpos cavernosos de ratos.

\title{
INFLUÊNCIA DO ESTRESSE OXIDATIVO SOBRE A RESPOSTA À ANGIOTENSINA II EM CARÓTIDA CONTRA-LATERAL À LESÃO POR CATÉTER-BALÃO DE RATO DIABÉTICO
}

\author{
Larissa Pernomian \\ Orientadora: Profa. Dra. Ana Maria de Oliveira \\ Tese de Doutorado apresentada em 16/02/2012
}

A lesão por catéter-balão deflagra uma resposta neurocompensatória acompanhada por uma hiperreatividade contrátil à angiotensina II na artéria carótida contra-lateral, que compensa a hiporresponsividade da artéria carótida ipsilateral ao agonista peptídico. Apesar da hiperreatividade contrátil, o fluxo sanguíneo da artéria carótida contra-lateral se mantém normal para compensar a redução no fluxo sanguíneo da artéria carótida ipsi-lateral, decorrente da formação da camada neoíntima. Considerando que o Diabetes mellitus tipo I induz a uma neurodegeneração generalizada, e que os mecanismos compensatórios à lesão por catéter-balão, observados na artéria carótida contra-lateral, são resultantes de um fenômeno neuronal, nós investigamos as consequências da lesão por catéter-balão sobre a contração induzida por angiotensina II e sobre o fluxo sanguíneo em artéria carótida contra-lateral de rato diabético tipo I. Para tanto, ratos Wistar adultos foram submetidos à indução do Diabetes tipo I por injeção intraperitoneal de estreptozotocina. Os ratos diabéticos foram submetidos à lesão por catéter-balão em carótida comum esquerda, 28 dias após o tratamento com estreptozotocina. 15 dias após a lesão vascular, curvas concentração-efeito cumulativas para angiotensina II foram obtidas em anéis de artéria carótida contra-lateral de rato diabético, em ausência ou presença de endotélio, tiron (seqüestrador de superóxido), PEG-catalase (seqüestrador de peróxido de hidrogênio), dimetiltiouréia (seqüestrador de radicais hidroxila), L-NNA (inibidor seletivo de óxido nítrico sintase endotelial, $e$ NOS), L-NPA (inibidor seletivo de óxido nítrico sintase neuronal, $n$ NOS) ou SC560 (inibidor seletivo de ciclooxigenase 1, COX 1). O fluxo sanguíneo foi determinado em artéria carótida contra-lateral de rato diabético, 15 dias após a lesão. A lesão por catéter-balão atenuou a hiperreatividade contrátil diabética à angiotensina II em carótida contra-lateral de rato diabético, por mecanismos mediados por peróxido de hidrogênio e radicais hidroxila derivados de $n$ NOS endotelial. O aumento residual da contração induzida por angiotensina II nessa artéria é mediado por superóxido derivado de $e$ NOS desacoplada, de origem muscular e/ou adventícia, por um mecanismo dependente de metabólitos de COX 1. Esse aumento de contração compensa a hiporresponsividade da artéria carótida ipsilateral de rato diabético à angiotensina II. A atenuação da hiperreatividade contrátil diabética à angiotensina II em carótida contra-lateral de rato diabético é concomitante à restauração do fluxo sanguíneo local, que compensa o fluxo sanguíneo prejudicado na artéria carótida ipsi-lateral de rato diabético. Os efeitos protetores deflagrados pela lesão por catéter-balão sobre o controle do tônus e do fluxo em artéria carótida contra-lateral de rato diabético apontam uma significância fisiopatológica vasoprotetora aos mecanismos compensatórios à lesão por catéter-balão. 


\title{
EFEITO INIBITÓRIO DO CAPTOPRIL SOBRE A METALOPROTEINASE-2 DA MATRIZ EXTRACELULAR (MMP-2) in vitro
}

\author{
Luciana Bärg Kuntze \\ Orientadora: Profa. Dra. Raquel Fernanda Gerlach \\ Dissertação de Mestrado apresentada em 27/02/2012
}

A MMP-2 é uma protease que está envolvida em muitos eventos fisiológicos e patológicos e que compartilha similaridades estruturais com a enzima conversora de angiotensina (ECA), de modo que os inibidores da ECA passaram a ser estudados com relação ao efeito inibitório também sobre a MMP-2. No entanto, este potencial inibitório não foi ainda testado na MMP-2 altamente purificada. Este estudo teve como objetivo investigar o potencial inibitório do captopril sobre a atividade da MMP-2. Primeiramente, supôs-se que a dissolução do captopril poderia induzir a mudanças no pH de soluções tampão. Em segundo lugar, avaliou-se o efeito direto do captopril sobre a MMP-2 presente no plasma humano e a MMP-2 recombinante humana (rhMMP-2) produzida e purificada de E. coli. As análises de atividade in vitro incluíram zimogramas com gelatina e ensaios fluorimétricos com DQ gelatin. A solubilização do captopril reduziu significativamente o pH da solução tampão 50 mM (p<0,01) mas não alterou o pH da solução tampão $200 \mathrm{mM}$ (p>0,05). Resultados de zimografia do plasma e da rhMMP-2 mostraram inibição da atividade gelatinolítica com significância estatística somente em concentrações iguais ou maiores que 4 e $1 \mathrm{mM}$ de captopril, respectivamente $(\mathrm{p}<0,05)$. A presença de captopril nos ensaios de fluorimetria resultaram na inibição significante da atividade de rhMMP-2 somente em concentrações iguais ou maiores que $2 \mathrm{mM}$ ( $\mathrm{p}<0,01)$, enquanto a rhMMP-2 ativada com APMA apresentou inibição significativa diante de 0,5 mM de captopril $(\mathrm{p}<0,01)$. As concentrações de captopril efetivas em inibir a MMP-2 in vitro foram muito superiores àquelas referentes à concentração plasmática máxima encontrada no plasma humano após a administração de uma dose de 50 mg de captopril. Em conjunto nossos resultados sugerem que o captopril não parece promover inibição significativa da MMP2 nas concentrações relatadas in vivo. Além disso, o pH das soluções tamponantes é um aspecto que requer mais atenção durante ensaios de inibição de protease in vitro.

\section{EFEITO DO AGONISTA DA VIA Hedgehog, PURMORFAMINA, NA DIFERENCIAÇÃO OSTEOGÊNICA DE CÉLULAS-TRONCO MESENQUIMAIS E OSTEOBLASTOS}

\author{
Fabíola Singaretti de Oliveira \\ Orientador: Prof. Dr. Adalberto Luiz Rosa \\ Tese de Doutorado apresentada em 28/02/2012
}

A via de sinalização Hedgehog (Hh) está envolvida, em vertebrados, no desenvolvimento de órgãos e membros assim como na formação do esqueleto. A regulação da via Hh é feita pela proteína inibitória Patched-1 (Ptch1) e a proteína Smoothened (Smo) é responsável pela ativação da cascata de transdução de sinal. Estudos in vitro sugerem que a ativação da via Hh é dependente do estágio de diferenciação osteogênica e da espécie avaliada. Portanto, o objetivo do presente estudo foi investigar o papel da via de sinalização Hh em células de humanos e de rato, ambas em estágios de diferenciação osteogênica distintos. Para isso, optou-se por modular a via Hh pela estimulação ou bloqueio de Smo, com purmorfamina e KAAD-Cyclopamine, respectivamente. Células-tronco mesenquimais (CTM) e osteoblastos, derivados de humanos e de ratos, foram cultivados em presença de veículo (dimetilsulfóxido) ou $2 \mu \mathrm{M}$ de purmorfamina, por períodos de até 21 dias. Foram avaliados os seguintes parâmetros: expressão do gene GLI1, envolvido na ativação da via Hh, e dos genes marcadores de osteoblastos, runt-related transcription factor 2 (RUNX2) e alkaline phosphatase (ALP), atividade de fosfatase alcalina (ALP) e formação de matriz mineralizada. Os dados foram submetidos ao teste de Mann Witney ou ao teste t, seguido de correção de Benjamini e Hochberg ou ainda ao teste de Kruskall-Wallis, sendo o nível de significância considerado $5 \%$. Os resultados mostraram que o agonista da via Hh, purmorfamina, promove a ativação da via, observada pelo aumento da expressão do gene GLI1, em todos os tipos celulares avaliados. Entretanto, na dependência do estágio de diferenciação osteogênica (CTM e osteoblastos) e da espécie (humano e rato), o perfil de expressão dos genes marcadores de osteoblastos foi diferente. Ainda, a purmorfamina aumentou a expressão de marcadores do fenótipo osteoblástico, como a atividade de ALPe mineralização, apenas em células derivadas de ratos. Os resultados sugerem que a participação da via Hh no processo de diferenciação osteogênica é dependente da espécie e do estágio de diferenciação osteogênica. 


\title{
INTERAÇÃO ENTRE OS SISTEMAS CANABINOIDE E NITRÉRGICO NA MODULAÇÃO DE COMPORTAMENTOS DEFENSIVOS EM RATOS: ENVOLVIMENTO DA SUBSTÂNCIA CINZENTA PERIAQUEDUTAL DORSOLATERAL
}

\author{
Sabrina Francesca de Souza Lisboa \\ Orientador: Prof. Dr. Francisco Silveira Guimarães \\ Tese de Doutorado apresentada em 01/03/2012
}

O estímulo de receptores CB1 (CB1) na substância cinzenta periaquedutal dorsolateral (SCPdl) leva à diminuição do comportamento de ansiedade em ratos submetidos ao labirinto em cruz elevado, enquanto a facilitação da transmissão nitrérgica nesse local leva à produção de comportamentos de fuga e de ansiedade. Nesta estrutura foram descritas tanto a isoforma neuronial da enzima sintase do óxido nítrico (nNOS) quanto receptores CB1. A interação entre os sistemas canabinoide e nitrérgico foi sugerida em outras regiões do sistema nervoso central, porém ainda era desconhecido se eles interagiam na SCPdl. Nosso objetivo geral, portanto, foi verificar a possível ocorrência desta interação na SCPdl na modulação de comportamentos defensivos. Para isso, realizamos experimentos para testar as hipóteses de que: 1. a hipolocomoção ou reações de fuga induzidas por doadores de NO intra-SCPdl seriam atenuadas pela modulação do sistema canabinoide local; 2. a facilitação da sinalização canabinoide na SCPdl atenuaria a supressão comportamental no teste de conflito de Vogel; 3. a anandamida e o NO interagiriam na SCPdl para modular o comportamento de ansiedade após exposição ao labirinto em cruz elevado; 4. A anandamida na SCPdl atenuaria a resposta de medo frente ao predador via receptores CB1. Em conclusão, nossos resultados sugerem que existe uma interação funcional e, muitas vezes complexa, entre os sistemas canabinoide e nitrérgico na SCPdl na modulação de respostas defensivas, provavelmente por modulação da liberação de glutamato. Tais resultados são importantes para o melhor entendimento dos mecanismos envolvidos nos efeitos produzidos pela modulação do sistema canabinoide na SCPdl em respostas defensivas.

\section{Fisiologia}

\section{EFEITOS DA KISSPEPTINA SOBRE A ATIVIDADE DO EIXO HIPOTÁLAMO-HIPÓFISE-ADRENAL E MEDIAÇÃO ESTROGÊNICA}

\author{
Iracema Gomes deAraujo \\ Orientador: Prof. Dr. Celso Rodrigues Franci \\ Dissertação de Mestrado apresentada em 12/01/2012
}

O eixo hipotálamo - hipófise - gônadas (HHG) é finamente modulado por uma rede neural e neuroendócrina complexa e por fatores ambientais fornecendo informações precisas acerca de parâmetros endógenos e exógenos que influenciam a reprodução. Acredita-se que a maioria dessas informações converge ao sistema Kisspeptina/GPR54, que as integra para controle do eixo HHG. Nesse contexto, sabe-se que o eixo hipotálamo - hipófise - adrenal (HHA) é um modulador importante da função reprodutiva. Portanto, considerando a comunicação entre os eixos HHG e HHA e ação do sistema Kisspeptina/ GPR54 no eixo HHG, nosso objetivo foi avaliar a ação da Kisspeptina sobre o eixo HHA e uma possível modulação estrogênica. Para tanto, ratas Wistar (240-260 g) ovariectomizadas (OVX) e portadoras de cânula-guia no ventrículo lateral esquerdo foram tratadas com cipionato de estradiol (10 $\mathrm{g}$ /animal; OVX-E2) ou veículo (OVX) durante 3 dias. No segundo dia de tratamento, as ratas foram submetidas à canulação da veia jugular para as coletas de sangue. No terceiro dia e 30 minutos após a coleta de sangue basal, veículo (Salina isotônica) ou Kisspeptina (0,3 ou 3nM/animal) foram administrados intracerebroventricularmente; as demais coletas foram realizadas após 15, 30, 60 e 120 minutos. Após a última coleta, os animais foram anestesiados e transcardiacamente perfundidos e os cérebros coletados para os procedimentos imunohistoquímicos. A administração de 0,3 (15 minutos) e 3,0nM/animal (15 e 30 minutos) de Kisspeptina aumentou a secreção de hormônio luteinizante no grupo OVX, e o estrógeno prolongou esta resposta na dose de 3nM/animal (15, 30 e 120 minutos) em relação aos respectivos controles. A Kisspeptina aumentou a secreção de hormônio folículo-estimulante no grupo OVX nas doses 0,3 (15, 30, 60 e 120 minutos) e 3,0nM/animal (15, 30, 60 e 120 minutos), assim como no grupo 
OVX-E2 na dose de 3,0nM/animal (15, 60 e 120 minutos) em relação aos respectivos controles. A administração de 3,0nM/ animal de Kisspeptina reduziu a secreção de corticosterona no grupo OVX (15 e 30 minutos vs. OVX+Salina e vs. respectivo valor basal) enquanto que, no grupo OVX-E2, ambas as doses reduziram esta secreção aos 15 minutos (Kiss 0,3 e 3,0 vs. OVX-E2 + Salina, respectivamente). Observamos ainda redução na secreção de progesterona nos grupos controle OVX (60 minutos) e OVX-E2 (15, 30, 60 e 120 minutos) quando comparado aos respectivos valores basais. A administração de $0,3 \mathrm{nM} /$ animal de Kisspeptina retardou essa queda na secreção de progesterona aos 30 minutos no grupo OVX-E2 quando comparado ao OVX-E2+Salina e, a maior dose, intensificou a queda em suas concentrações. Adicionalmente, a administração de 3nM/animal de Kisspeptina reduziu o número de neurônios imunorreativos para proteína FRA (do inglês Fos-related antigen, expressa em núcleos de neurônios em atividade basal) e CRH (hormônio liberador de corticotrofina) ou AVP (vasopressina) na porção medial do núcleo paraventricular (PVN) hipotalâmico somente no grupo OVX quando comparado ao respectivo controle. Dessa forma, podemos sugerir que a Kisspeptina atue sobre o eixo HHA, inibindo-o e, que tal resposta parece envolver os neurônios parvocelulares CRH e AVPérgicos do PVN, e o estrógeno parece atenuar a ação da Kisspeptina sobre o eixo HHA.

\title{
ATIVAÇÃO PARASSIMPÁTICA PELA PIRIDOSTIGMINA NA FASE PRECOCE DA INSUFICIÊNCIA CARDÍACA: EFEITO SOBRE A MODULAÇÃO AUTONÔMICA E FUNÇÃO CARDÍACA
}

\author{
Daniel Penteado Martins Dias \\ Orientador: Prof. Dr. Hélio Cesar Salgado \\ Tese de Doutorado apresentada em 15/02/2012
}

A insuficiência cardíaca (IC) promove alterações cardiovasculares e centrais, afetando a modulação autonômica do miocárdio. Com o estabelecimento e progressão da IC, a inervação autonômica do coração sofre modifícações estruturais e funcionais, afetando o balanço simpatovagal cardíaco induzindo hiperatividade simpática e atenuação da atividade parassimpática. Embora a facilitação da atividade parassimpática, no sentido de se melhorar o balanço simpatovagal, seja de difícil abordagem, esta pode ser induzida pela inibição da ação da acetilcolinesterase. Todavia, o efeito do bloqueio da acetilcolinesterase, pela piridostigmina, ainda não foi estudado na fase precoce da insuficiência cardíaca, tanto em humanos como em animais de experimentação. O presente estudo teve por objetivo avaliar a influência da administração de piridostigmina por 12 dias, sobre o balanço simpatovagal cardíaco, variabilidade cardiocirculatória, sensibilidade barorreflexa e função cardíaca de ratos da linhagem Sprague Dawley. Os animais foram implantados com sondas de telemetria para registro do eletrocardiograma e submetidos a ligadura coronária e administração de piridostigmina. Os ratos foram divididos em 4 grupos: controle, piridostigmina (PI), insuficiência cardíaca (IC), IC+PI. Após 1 dia da ligadura coronária, ratos com IC apresentaram redução na potência da banda de LF, aumento na potência da banda de HF e redução na razão LF/HF, do espectro do intervalo cardíaco. Após 1 dia da cirurgia, a administração de piridostigmina não promoveu modificações nas potências das bandas de LF e HF do espectro do intervalo cardíaco, assim como na razão LF/HF em ratos controles, mas previniu a redução da razão LF/HF em ratos com IC. Após 5 dias da cirurgia, não foram observadas modificações na variabilidade do intervalo cardíaco nos grupos estudados. Ratos com IC apresentaram aumento da frequiência cardíaca (FC) basal, redução do efeito vagal e aumento do efeito simpático cardíaco. A piridostigmina promoveu redução da FC basal e aumento do efeito vagal tanto em ratos controles como em ratos com IC. A frequiência intrínseca de marcapasso foi semelhante entre os grupos estudados. Observou-se redução na pressão arterial média (PAM) de ratos com IC, mas a piridostigmina não modificou a PAM tanto de ratos controles como de ratos com IC. Ratos com IC apresentaram redução da potência da banda de LF do espectro da pressão arterial sistólica (PAS). A piridostigmina reduziu a potência da banda de LF do espectro da PAS de ratos controles. A sensibilidade baroreflexa foi semelhante entre os grupos estudados. Ratos com IC apresentaram menor fração de ejeção, maior volume diastólico final, maior volume sistólico final, menor $+\mathrm{dP} / \mathrm{dt}$, menor -dP/dt e maior pressão diastólica final. A piridostigmina não modificou a função cardíaca dos grupos estudados e não modificou a extensão da área isquêmica dos ratos submetidos a ligadura coronária. Em conclusão, a administração de piridostigmina em ratos com IC reduziu a FC basal, aumentou o tono vagal cardíaco, além de prevenir a redução da razão LF/HF do espectro do intervalo cardíaco 1 dia após a ligadura coronária. Nos ratos controles, a piridostigmina reduziu a FC basal, reduziu a potência da banda de LF do espectro da PAS, e aumentou o tono vagal cardíaco. A piridostigmina não modificou, tanto nos ratos controles como nos ratos com IC, a função cardíaca e não modificou a extensão da área isquêmica dos ratos submetidos a ligadura coronária. 


\title{
ANÁLISE DAS ATIVIDADES SIMPÁTICA E RESPIRATÓRIA DE RATOS JOVENS SUBMETIDOS À HIPÓXIA CRÔNICA INTERMITENTE APÓS INIBIÇÃO DAS CÉLULAS GLIAIS NO NÚCLEO DO TRATO SOLITÁRIO
}

\author{
Kaue Machado Costa \\ Orientador: Prof. Dr. Benedito H. Machado \\ Dissertação de Mestrado apresentada em 16/02/2012
}

Nesse estudo, investigamos a possível participação das células gliais do núcleo do trato solitário (NTS) na modulação da atividade simpática e respiratória. Para alcançar esse objetivo, utilizamos a working heart-brainstem preparation (WHBP) de ratos jovens associada às microinjeções bilaterais de fluorocitrato (FCt; $1 \mathrm{nmol} / 20 \mathrm{~nL})$, um inibidor específico de células gliais, no NTS intermediário e caudal. A microinjeção de FCt no NTS, no entanto, não promoveu alterações significativas na freqüência respiratória, magnitude da atividade simpática, duração da inspiração ou duração da expiração em relação aos grupos controle. Adicionalmente, investigamos se a atividade de células gliais no NTS é importante para a expressão das adaptações simpáticas e respiratórias à exposição à hipóxia crônica intermitente (HCI) por meio da microinjeção de FCt em animais previamente expostos a esse desafio fisiológico. No caso desses animais, a microinjeção de FCt no NTS também não promoveu alterações significativas na freqüência respiratória, magnitude da atividade simpática e na duração da inspiração e da expiração em relação aos respectivos grupos controle. A inativação de células gliais também não alterou o padrão de acoplamento simpático-respiratório em nenhum dos grupos analisados. As evidências obtidas indicam que as células da glia no NTS intermediário e caudal não participam tonicamente da modulação das vias eferentes da atividade simpática e respiratória em animais expostos a HCI e em animais controle. Ainda que os nossos resultados indiquem que a inibição metabólica de células da glia no NTS agudamente não altera os padrões simpático e respiratório basais em ratos controle e HCI, estudos adicionais serão necessários para avaliar as implicações da inibição a longo prazo desse grupamento celular em fenômenos de adaptação e plasticidade no NTS.

\section{CORTEX CINGULADO ANTERIOR E COMPORTAMENTO NOCICEPTIVO EM COBAIAS: MODULAÇÃO GABAÉRGICA, COLINÉRGICA E OPIOIDÉRGICA}

\author{
João Zugaib Cavalcanti \\ Orientadora: Profa. Dra. Leda Menescal de Oliveira \\ Dissertação de Mestrado apresentada em 23/02/2012
}

A dor é um fenômeno multidimensional, que geralmente desencadeia reações emocionais desconfortáveis quando identificada. Sua relação com injúria tecidual pode ser interpretado como um mecanismo adaptativo de defesa à integridade do organismo, tendo em vista sua preservação evolutiva. Porém, o substrato neurobiológico do organismo parece determinar a complexificação do repertório comportamental em diferentes espécies. Nesse sentido, o córtex cingulado anterior (CCA) tem sido amplamente descrito em mamíferos modulando diferentes aspectos da dor. O presente trabalho utilizou os testes algesimétricos de vocalização e da formalina em cobaias, para se avaliar o decurso temporal do efeito da microinjeção de agonistas e antagonistas GABAérgico (muscimol e bicuculina); colinérgico (carbacol e atropina) e opioidérgico (morfina e naloxona). A microinjeção de bicuculina ( $1 \mathrm{nmol} /$ 0,2 $\mu \mathrm{l}$ ) exacerbou as respostas nociceptivas em ambos os testes, porém diferentes doses de muscimol $(0,5,1$ e $2 \mathrm{nmol} / 0,2 \mu \mathrm{l})$, não modificaram as respostas. O efeito da bicuculina foi bloqueado em ambos os testes pela microinjeção prévia de muscimol ( $1 \mathrm{nmol} / 0,2 \mu \mathrm{l})$ no CCA. A microinjeção de carbacol $(2,7 \mathrm{nmol} / 0,2 \mu \mathrm{l})$ neste substrato promoveu antinocicepção, evidenciada por meio da atenuação da amplitude das vocalizações, mas não pelo teste da formalina. Esse efeito foi bloqueado pela administração prévia de atropina $(0,7$ $\mathrm{nmol} / 0,2 \mu \mathrm{l})$ e de naloxona $(2,7 \mathrm{nmol} / 0,2 \mu \mathrm{l})$. A microinjeção de morfina $(4,4 \mathrm{nmol} / 0,2 \mu \mathrm{l})$ promoveu antinocicepção em ambos os testes. Concluímos que a inibição do tônus GABAérgico no CCA exacerba os comportamentos nociceptivos e que a antinocicepção promovida por carbacol pode ter sido mediada pelo sistema de opióides endógenos, tendo em vista o bloqueio do seu efeito com naloxona. Além disso, a estimulação opióide promove uma contundente antinocicepção. 


\section{ANÁLISE COMPARATIVA DA NEURODEGENERAÇÃO E NEUROGÊNESE APÓS Status Epilepticus INDUZIDO POR ADMINISTRAÇÃO SISTÊMICA E MICROINJEÇÕES NA FORMAÇÃO HIPOCAMPAL DE PILOCARPINA E EXTRATO BRUTO DE CARAMBOLA EM MODELOS DE EPILEPSIA DO LOBO TEMPORAL}

\section{Olagide Wagner de Castro}

Orientador: Prof. Dr. Norberto Garcia Cairasco

Tese de Doutorado apresentada em 27/02/2012

Epilepsia é definida como descargas paroxísticas anormais de populações neuronais em processos que afetam a excitabilidade cortical e do encéfalo como um todo, caracterizando-se pela ocorrência periódica de crises epilépticas, que podem ser convulsivas ou não. Cerca de 1 a $2 \%$ da população mundial é portadora de epilepsia e aproximadamente $30 \%$ dos acometidos são resistentes ao tratamento com drogas antiepilépticas e, desses, a maioria apresenta Epilepsia do Lobo Temporal (ELT), que se caracteriza pela ocorrência de crises que se iniciam em estruturas do lobo temporal, como hipocampo, complexo amigdaloide e adjacências. Os pacientes com ELT podem apresentar Status Epilepticus (SE), que é definido como uma crise de longa duração ou pequenas crises sem recuperação entre elas. No presente estudo foram feitas injeções intra-hipocampais e sistêmicas de pilocarpina (PILO) para indução de SE (ratos e camundongos), mimetizando ELT. Posteriormente foram analisados fenômenos plásticos associados à presença de SE. Os resultados gerados foram subdivididos em capítulos e apresentados abaixo:

1) A injeção de PILO sistêmica (S-PILO) e microinjeção de PILO intra-hipocampal (H-PILO), são capazes de induzir SE e processos neurodegenerativos identificados pela histoquímica de Fluoro-Jade (FJ). Foi observado que áreas FJ+ são mais abrangentes em S-PILO que H-PILO.

2) Foram usados os modelos H-PILO e microinjeção de extrato bruto de carambola para induzir SE e observou-se que a cinética de neurodegeneração FJ+ no grupo carambola foi similar ao encontrado em H-PILO. Os animais foram perfundidos 24 h, 7 e 15 dias após SE e foram mapeadas 5 áreas cerebrais, que são parte da circuitaria hipocampal: Hilus, CA3, CA1, subiculum e córtex entorrinal. Foi observado nos dois modelos (H-Pilo e extrato carambola) neurodegeneração FJ+ coincidentes no Hilus e CA3 24 h após SE, em CA1 7 dias após SE e, apenas no grupo carambola, neurodegeneração mais cedo, no córtex entorrinal 24 h após SE. Posteriormente, foi analisada neurodegeneração apoptótica no Hilus do GD 15 dias após SE e, observou-se também, que o grupo H-PILO possui um maior número de células em apoptose nessa área. Por último, foi feita uma análise em relação à quantidade de novos neurônios na camada granular do GD e foi constatado que o grupo H-PILO também apresentou maior número de células novas quando comparado aos animais expostos à carambola. Entretanto, a quantidade de novos neurônios do grupo carambola é maior em relação ao grupo experimental, demonstrando, assim, que ocorre neurogênese significativamente maior que o basal.

3) Foram analisadas estruturas de dendritos apicais de células granulares que expressam green fluorescent protein (GFP), marcadas com Bromodeoxiuridina (BrdU) nascidas 2 meses antes da indução do SE em camundongos C57B/L6. Diferente das células granulares imaturas, as células granulares maduras expostas ao SE (maduras+SE) não tiveram rompimento de sua arborização apical dendrítica, entretanto elas exibiram uma redução significativa na densidade e no número de espinhos dendríticos quando comparadas às células granulares maduras da mesma idade não expostas ao SE (madura/sem SE).

4) Testamos a hipótese de que níveis aumentados de corticosterona (CORT), hormônio relacionado ao estresse, pode aumentar a atividade epileptiforme e o número de crises recorrentes espontâneas (CRE) em camundongos epilépticos induzidos por PILO subcutânea (s.c.). A atividade Vídeo-EEGráficas foi monitorada 24 horas por dia por um período de 4 semanas ou mais, enquanto os animais eram tratados serialmente com CORT e veículo (propilenoglicol) também s.c. A administração de CORT aumentou a frequência e a duração dos eventos epileptiformes nas primeiras 24 horas de tratamento e estes efeitos persistiram por pelo menos 2 semanas após o término das injeções. Injeções de veículo produziram aumento modesto na atividade epileptiforme nas primeiras 24 horas, entretanto, os efeitos na atividade epileptiforme não foram persistentes. A administração de CORT ou veículo não foram capazes de aumentar significativamente a frequência das CREs: embora um pequeno número de animais respondesse de forma exuberante ao tratamento de CORT.

5) Por último foi feito um estudo farmacológico, no qual foi calculada a ED50 para PILO sistêmica e intra-hipocampal que foi de $174 \mathrm{mg} / \mathrm{kg}$ e 2,46 $\mu \mathrm{g} / \mathrm{kg}$ respectivamente. As doses sugeridas aqui (cerca de $5 \mu \mathrm{g} / \mathrm{kg}: 1 \mathrm{~mL}$ de $1200-1400 \mu \mathrm{g} / \mathrm{mL}$ de solução de PILO para microinjeção intra-hipocampal e $320 \mathrm{mg} / \mathrm{kg}$ para injeção sistêmica) são próximas da metade do padrão de PILO descrita na literatura para ambas as rotas de injeção de PILO. Nossos dados indicam que, para camundongos, a ED50 é similar a LD50, sugerindo que não é possível aumentar o número de animais que entram em SE. 
O conjunto de dados fornece importantes evidências relacionadas aos processos epileptogênicos, indicando às áreas mais acometidas por processos neurodegenerativos e de neurogênese e ainda analisa a influência do estresse sobre as CREs. Intervenções neuroplásticas nesta etapa da implementação da síndrome epiléptica poderão contribuir para o desenvolvimento de terapias antiepilépticas que representarão um passo importante em busca de uma possível cura.

\title{
INFLUÊNCIA DO ESTRADIOL SOBRE AS ALTERAÇÕES NEUROENDÓCRINAS E DO EQUILÍBRIO HIDROELETROLIITICO INDUZIDAS PELA ADRENALECTOMIA EM RATAS
}

\author{
Gislaine de Almeida Pereira \\ Orientador: Prof. Dr. José Antunes Rodrigues \\ Dissertação de Mestrado apresentada em 28/02/2012
}

Nas últimas décadas, têm-se apreciado muito o estudo da influência dos hormônios gonadais, especialmente os estrógenos, sobre o controle do equilíbrio hidreletrolítico, uma vez que são observadas alterações no balanço hidromineral associadas às diferentes fases do ciclo reprodutivo, período de gestação e senescência reprodutiva. Além disso, evidências experimentais demonstram o envolvimento do eixo hipotálamo hipófise adrenal (HPA) no controle do equilíbrio hidroeletrolítico, bem como a influência dos estrógenos na modulação deste eixo. Entretanto, a relevância fisiológica dos achados da atividade do eixo HPA em fêmeas ainda não está totalmente elucidado, principalmente aquela relacionada ao controle da homeostase dos fluidos corporais assim como aquela relacionada com a vida reprodutiva em fêmeas. Portanto, o objetivo deste trabalho foi avaliar os efeitos do tratamento prévio com estradiol (E2) sobre as alterações neuroendócrinas e do equilíbrio hidroeletrolítico induzidas pela adrenalectomia (ADX), com ou sem reposição hormonal de glicocorticóides em ratas Wistar ovariectomizadas (OVX). Para isso ratas Wistar (230-250g) foram ovariectomizadas bilateralmente e tratadas durante quatorze dias com veículo (óleo de milho) ou cipionato de estradiol ( $20 \mu \mathrm{g} / 0,2 \mathrm{~mL} / \mathrm{animal}$ ). Após sete dias de tratamento com E2 os animais foram submetidos à adrenalectomia bilateral, iniciando-se a reposição com corticosterona $(10 \mathrm{mg} / \mathrm{kg} / 0,2 \mathrm{~mL})$ ou administração de veículo (óleo de milho em $5 \%$ de etanol) durante os sete dias restantes. Os resultados obtidos demonstram que somente o tratamento com E2 em ratas OVX e adrenais intactas foi capaz de atenuar o apetite ao sódio e natriurese em condições basais, assim como reduzir os níveis de RNAm do receptor AT1 no órgão subfornicial (SFO). O tratamento prévio com E2 também atenuou as respostas homeostáticas, apetite ao sódio e natriurese, induzidas pela ADX, modulando as respostas hormonais desencadeadas pela mesma e reduzindo a expressão de RNAm de AT1 no SFO. O E2 modulou o efeito induzido pelo tratamento com CORT, em ratas adrenais intactas, sobre o apetite ao sódio, reduzindo este efeito. Adicionalmente, o tratamento prévio com E2 atenuou a expressão do RNAm do fator liberador de corticotropina (CRF) no núcleo paraventricular (PVN) induzida pela ADX. Desta forma diminuiu a responsividade da atividade do eixo HPA, em condições de ADX. E aumentou a expressão do RNAm de CRF no PVN em ratas ADX repostas com corticosterona, alterando o feedback negativo exercido pela mesma sobre a atividade do eixo HPA em condições de ADX. O conjunto desses resultados demonstra que o E2 apresenta um importante papel na modulação das respostas comportamentais e neuroendócrinas envolvidas com a manutenção da homeostase hidroeletrolítica, tanto em condições basais quanto em resposta a ADX.

\section{EFEITO DA ESTIMULAÇÃo COLINÉRGICA DA ÁREA SEPTAL MEDIAL (ASM) NA MODULAÇÃo DAS RESPOSTAS NEUROENDÓCRINAS ENVOLVIDAS NO CONTROLE DO VOLUME E OSMOLALIDADE DOS LÍQUIDOS ORGÂNICOS}

\author{
Renata Fabris Paulin \\ Orientador: Prof. Dr. José Antunes Rodrigues \\ Tese de Doutorado apresentada em 19/03/2012
}

Estudos prévios demonstraram a importância das vias colinérgicas para o controle da secreção de hormônios, bem como sua participação na regulação do balanço hidroeletrolítico (Antunes-Rodrigues et al. 2004; Johnson e McKinley, 2004). A área septal medial (ASM) é uma importante estrutura prosencefálica envolvida com a regulação cardiovascular e controle do balanço hidroeletrolítico. A ativação colinérgica da ASM produz resposta pressora, dipsogênica e natriurética no rato. Estudos de Mahon et al. (1995) demonstraram que a estimulação colinérgica da ASM induz a expressão da proteína 
Fos no núcleo preóptico mediano (MnPO), no órgão vasculoso da lâmina terminal (OVLT), no órgão subfornicial (SFO), no núcleo paraventricular do hipotálamo (PVN) e no núcleo supraótico (SON).

Nesse estudo, verificamos os efeitos da estimulação colinérgica da ASM sobre: 1) a ingestão de água e sódio; 2) excreção urinária de sódio e água; 3 ) secreção dos hormônios vasopressina (AVP), ocitocina (OT) e do peptídeo natriurético atrial (ANP), 4) expressão da proteína Fos em neurônios vasopressinérgicos e ocitocinérgicos em neurônios do PVN e SON; 5) expressão do RNAm dos peptídeos hipotalâmicos (OT e AVP) em estruturas hipotalâmicas (PVN e SON) por meio da técnica de Real Time-PCR), 6) expressão do RNAm dos peptídeos hipotalâmicos (OT e AVP) em estruturas hipotalâmicas (PVN e SON) por meio da técnica hibridização in situ. 7) conexão da ASM e de seus receptores colinérgicos com áreas prosencefálicas e do tronco cerebral através da injeção de traçador retrógrado (Fluoro-Gold-FG) e anterógrado (Dextrana Amina Biotinilada-BDA) e de carbacol na ASM.

Em nosso estudo verificamos um aumento da ingestão de água, excreção de sódio, secreção hormonal de vasopressina e ocitoicina, além da expressão de c-Fos e de RNAm dos peptídeos hipotalâmicos (OT e AVP) nos neurônios vasopressínergicos e ocitocinérgicos do PVN e SON em resposta ao estímulo colinérgico na ASM. Além disso, visualizamos o aumento da expressão de RNAm de OT e AVP nos núcleos hipotalâmicos do PVN e SON através da técnica de hibridização in situ. Outro dado importante foi que o antagonista colinérgico muscarínico (metil-atropina) na dose de $4 \mathrm{nmol} / 0,5 \mu \mathrm{L}$ injetado previamente na ASM foi capaz de reduzir as respostas produzidas pela injeção posterior de carbacol na ASM sobre a ingestão de água, excreção de sódio, secreção hormonal de vasopressina e ocitocina, na expressão da proteína Fos e de RNAm em neurônios vasopressinérgicos e ocitocinérgicos do PVN e SON. Também visualizamos a co-localização do traçador anterógrado Fos/BDA em neurônios da Banda Diagonal de Broca (HDB), na Área Hipotalâmica Lateral (LHA), na fimbria do Hipocampo (hf), no Núcleo Hipotalâmico Posterior (PH), na Substância cinzenta Periaqueductal (PAG), região dorsal do Núcleo Dorsal da Rafe (DRD) e na Área Postrema (AP). Também visualizamos a co-localização do traçador retrógrado, Fos/FG no HDB. No entanto, não ocorreu alteração da ingestão de sódio, excreção de água e concentração plasmática do hormônio natriurético atrial. Podemos sugerir através desse estudo que a ASM e seus receptores colinérgicos estão envolvidos na circuitaria neuronal responsável pela resposta dipsôgenica induzida pela injeção de carbacol na ASM e também na regulação central da secreção de AVP e OT, mas não de ANP e que dentre esses hormônios, o OT está envolvido na natriurese promovida pela injeção de carbacol na ASM.

\section{O PAPEL DAS CATECOLAMINAS NA REGULAÇÃO DA GLICEROQUINASE E SUA IMPORTÂNCIA NO TECIDO ADIPOSO BRANCO DE RATOS}

\section{Rafael Rossi Valentim}

Orientadora: Profa. Dra. Isis do Carmo Kettelhut

Dissertação de Mestrado apresentada em 21/03/2012

O presente trabalho teve como objetivo verificar os efeitos da infusão de noradrenalina utilizando minibombas osmóticas (minipumps) por 72 horas na via de fosforilação direta do glicerol no tecido adiposo branco de ratos. Foi avaliado o efeito da infusão de noradrenalina na atividade e conteúdo da gliceroquinase (GK) nos tecidos adiposos epididimal (EPI) e retroperitonial (RETRO) de ratos normalmente alimentados, jejuados por 48 horas, diabéticos e alimentados com dieta hipercalórica e hiperlipídica do tipo cafeteria (HCHL). Foram também verificadas as velocidades de incorporação de glicerol em glicerol-TAG e de liberação de glicerol e ácidos graxos para o meio de incubação por fragmentos de EPI in vitro. A infusão de noradrenalina promoveu um aumento da atividade da GK no TAB de animais normalmente alimentados, jejuados, diabéticos e alimentados com dieta cafeteria, indicando que a GK tem sua atividade estimulada pelas catecolaminas. Além disso, a atividade da GK parece ser também estimulada pela insulina, visto que é menor em ratos diabéticos e jejuados e maior em ratos HCHL, quando comparados com os animais normalmente alimentados. Quando avaliados in vitro, fragmentos de EPI de animais submetidos à infusão de noradrenalina apresentaram velocidade de incorporação de glicerol em glicerol-TAG aumentada e a liberação de ácidos graxos e glicerol para o meio de incubação reduzida, sugerindo que a maior atividade da GK intensifica a fosforilação do glicerol e previne que o glicerol e os ácidos graxos oriundos da lipólise sejam liberados pelo TAB. A inibição in vitro da GK aumentou a liberação de glicerol para o meio de incubação pelos fragmentos de TAB quando as demais vias de síntese de G3P foram também bloqueadas. Em conjunto nossos resultados sugerem que as catecolaminas e a insulina interagem para regular a via de fosforilação direta do glicerol, e que alterações na atividade da GK podem interferir no metabolismo lipídico do TAB, regulando a reesterificação e a liberação dos produtos da lipólise (ácidos graxos e glicerol), independentemente da atividade lipolítica. Como consequiência deste achado, a liberação de glicerol para o meio de incubação representa de forma precisa a atividade lipolítica do $\mathrm{TAB}$, apenas quando a atividade da GK é igual nas diferentes condições experimentais estudadas. 


\title{
EXPRESSÃO DE RECEPTORES PARA ESTRÓGENO E ATIVIDADE DE NEURÔNIOS VASOPRESSINÉR- GICOS EM RATAS OVARIECTOMIZADAS SOB ESTIMULAÇÃO OSMÓTICA
}

\author{
Fabiana Lucio de Oliveira
}

Orientador: Prof. Dr. Celso Rodrigues Franci

Tese de Doutorado apresentada em 29/03/2012

A homeostase hidro-eletrolítica é controlada por informações sobre volume e a concentração dos íons dos líquidos corporais. Alterações da osmolalidade são detectadas por receptores presentes em diversas regiões do SNC, entre as quais os órgãos circunventriculares. Alterações conformacionais nestas células ativam neurônios localizados nos núcleos paraventricular (PVN) e supra-óptico (SON) do hipotálamo, que secretam ocitocina (OT) e vasopressina (AVP). A osmolalidade plasmática aumenta em consequiência da alimentação, o que induz a secreção de OT e AVP. Os esteróides ovarianos podem influenciar o balanço de líquidos, modulando sistemas hormonais que regulam tanto o consumo quanto a excreção de água, ou agindo diretamente em neurônios ocitocinérgicos e vasopressinérgicos do hipotálamo. No entanto, esta ação não é ainda entendida. É possível que esses sistemas respondam de forma diferente às variações de estrógeno, talvez por ação direta através de receptores de estrógeno tipo $\beta$ em neurônios OT e AVP do PVN e SON, e por ação indireta através de receptores de estrógeno tipo $\alpha$ em órgãos circunventriculares. O objetivo do presente trabalho foi avaliar a participação do estradiol na modulação da secreção de AVP em resposta ao estímulo osmótico induzido pela realimentação após jejum. Para tanto, foi realizada a determinação da concentração plasmática de AVP, a análise da ativação de neurônios AVP, o conteúdo protéico de ER $\beta$ no PVN e no SON bem como a ativação neuronal pela expressão de FOS e a expressão de ER $\alpha$ nos órgãos circunventriculares de animais ovariectomizados tratados com estradiol ou veículo. Os resultados mostram que a realimentação após jejum de 48 horas aumenta a expressão de FOS e a expressão da proteína de ER $\beta$ no PVN e SON, a expressão de FOS nos órgãos circunventriculares estudados e a concentração plasmática de AVP. No entanto, não foi observada diferença significativa entre os tratamentos. Houve uma inibição da expressão de ER $\alpha$ nos órgãos circunventriculares estudados. Aparentemente, o estradiol não participa da elaboração de uma resposta frente ao estímulo osmótico induzido pela realimentação e não interfe na ativação de neurônios AVP e na secreção desse hormônio para circulação sanguínea.

\section{Genética}

\section{CARACTERIZAÇÃO DO COMPORTAMENTO in vitro DE GENÓTIPOS DE CANA-DE-AÇÚCAR VISANDO O DESENVOLVIMENTO DE PLANTAS GENETICAMENTE MODIFICADAS VIA Agrobacterium TUMEFACIENS}

\author{
Alexandre Palma Boer Martins \\ Orientadora: Profa. Dra. Maria Helena de Souza Goldman \\ Dissertação de Mestrado apresentada em 10/01/2012
}

A otimização de procedimentos de cultivo in vitro como a regeneração direta e indireta de explantes, representam os maiores gargalos para a transformação genética da cana-de-açúcar mediada por Agrobacterium. Dessa forma, neste trabalho, objetivou-se avaliar a capacidade de regeneração direta e indireta de 11 cultivares de cana pertencestes ao Programa Cana IAC, com o intuito de se identificar genótipos mais promissores para ensaios de transformação genética. Assim, todos os genótipos que produziram calos embriogênicos foram submetidos à infecção com Agrobacterium tumefaciens em diferentes condições. Os explantes foram inoculados com as linhagens C58C1 e EHA-105 portando os vetares superbinários pSoup e pAL156, os quais contêm os genes bar (pat) e gus (uidA), em três densidades ópticas diferentes $\left(\mathrm{OD}_{600} 0.4 ; 0.6 ; 0.8\right)$. A análise da expressão do gene repórter GUS foi realizada em três genótipos selecionados. As maiores taxas de regeneração direta $(\sim 75 \%)$ e indireta $(\sim 70 \%)$ foram obtidas com a cultivar IACSP96-5000. Esta cultivar também apresentou as melhores taxas de regeneração indireta quando calos embriogênicos foram submetidos aos processos de infecção por Agrobacterium. Calos GUS-positivos, em uma taxa de 8.33\%, foram obtidas apenas para o genótipo IACSP95-5000 inoculado em uma $\mathrm{OD}_{600}=0,8$. A influência da cepa utilizada não se mostrou significativa para a capacidade de regeneração dos explantes, porém a cepa EHA-105 mostrou-se mais eficiente para o processo de transformação vegetal. Além disso, a forte dependência do genótipo foi evidenciada estatisticamente em todos os experimentas . Deste modo, cepas e OD's bactéria nas, a origem do explante e, principalmente o genótipo, parecem ser os fatores determinantes para o sucesso desta metodologia em cana-de-açúcar. 


\title{
ANÁLISE INTEGRATIVA DE PERFIS TRANSCRICIONAIS DE PACIENTES COM diabetes mellitus TIPO 1, TIPO 2 E GESTACIONAL, COMPARANDO-OS COM MANIFESTAÇÕES DEMOGRÁFICAS, CLÍNICAS, LABORATORIAIS, FISIOPATOLÓGICAS E TERAPÊUTICAS
}

\author{
Adriane Feijó Evangelista \\ Orientador: Prof. Dr. Eduardo Antonio Donadi \\ Tese de Doutorado apresentada em 09/03/2012
}

O diabetes mellitus tipo 1 (DM1) tem etiologia autoimune, enquanto o diabetes mellitus tipo 2 (DM2) e o diabetes mellitus gestacional (DMG) são considerados como distúrbios metabólicos. Neste trabalho, foi realizada análise do transcriptoma das células mononucleares do sangue periférico (do inglês, peripheral mononuclear blood cells - PBMCs), obtidas de pacientes com DM1, DM2 e DMG, realizando análises por module maps a fim de comparar características patogênicas e aspectos gerais do tratamento com anotações disponíveis de genes modulados, tais como: a) análises disponíveis a partir de estudos de associação em larga escala (do inglês genome-wide association studies - GWAS); b) genes associados ao diabetes em estudos clássicos de ligação disponíveis em bancos de dados públicos; c) perfis de expressão de células imunológicas fornecidos pelo grupo ImmGen (Immunological Project). Foram feitos microarrays do transcriptoma total da plataforma Agilent (Whole genome onecolor Agilent 4x44k) para 56 pacientes (19 DM1, 20 DM2 e 17 DMG). Para a compreensão dos resultados foram aplicados filtros não-informativos e as listas de genes diferencialmente expressos foram obtidas por análise de partição e análise estatística não-paramétrica (rank products), respectivamente. Posteriormente, análises de enriquecimento funcional foram feitas pelo DAVID e os module maps construídos usando a ferramenta Genomica. As análises funcionais contribuíram para discriminar os pacientes a partir de genes envolvidos na inflamação, em especial DM1 e DMG. Os module maps de genes diferencialmente expressos revelaram: a) genes modulados exibiram perfis de transcrição típicos de macrófagos e células dendríticas, b) genes modulados foram associados com genes previamente descritos como genes de complicação ao diabetes a partir de estudos de ligação e de meta-análises; c) a duração da doença, obesidade, número de gestações, níveis de glicose sérica e uso de medicações, tais como metformina, influenciaram a expressão gênica em pelo menos um tipo de diabetes. Esse é o primeiro estudo de module maps mostrando a influência de padrões epidemiológicos, clínicos, laboratoriais, imunopatogênicos e de tratamento na modulação dos perfis transcricionais em pacientes com os três tipos clássicos de diabetes: DM1, DM2 e DMG.

\section{AVALIAÇÃO DOS EFEITOS ANTINEOPLÁSICOS DA ZEBULARINA EM LINHAGENS PEDIÁTRICAS DE LEUCEMIA LINFOIDE AGUDA}

\author{
Augusto FariaAndrade \\ Orientador: Prof. Dr. Luiz Gonzaga Tone \\ Dissertação de Mestrado apresentada em 26/03/2012
}

A leucemia linfóide aguda (LLA) é a neoplasia hematológica mais comum na infância e representa uma doença heterogênea em relação à biologia e ao prognóstico e seu tratamento consiste principalmente em quimioterapia. Apesar dos avanços no tratamento, cerca de $20 \%$ dos pacientes apresentam recaída da doença e/ou óbito indicando a necessidade de terapias diferenciadas para esse grupo. Recentemente, drogas epigenéticas como inibidores de DNA metiltransferases (iDNMTs) tem mostrado efeitos anti-neoplásicos promissores para o tratamento de diversos tipos de neoplasias incluindo a LLA. Nos tumores, a hipermetilação gênica é encontrada em vários genes, incluindo genes de reparo do DNA, reguladores do ciclo celular e apoptose. Sendo assim, drogas desmetilantes estão sendo apontadas como promissores agentes para o tratamento do câncer. A Zebularina (ZB) é um iDNMT análogo de citidina que inibe a metilação do DNA. Esta droga tem mostrado resultados animadores para o tratamento de diversas neoplasias, incluindo glioblastoma, leucemia mielóide aguda, câncer de mama, próstata e outros. O objetivo deste trabalho foi avaliar os efeitos do tratamento com a ZB, associada ou não à quimioterápicos, em linhagens celulares pediátricas de LLA, por meio de ensaios funcionais como proliferação celular, capacidade clonogênica, apoptose e ciclo celular. Além disso, foi analisada a capacidade desmetilante da droga e a expressão dos genes DNMT1, DNMT3a e DNMT3b após o tratamento com a ZB. A ZB inibiu a proliferação celular de maneira dose e tempo-dependente e agiu sinergicamente quando combinada com o MTX em ambas as linhagens. Ela também diminuiu a capacidade clonogênica e aumentou a taxa de apoptose nas duas linhagens estudadas. Além disso, o tratamento com ZB causou uma parada na fase $\mathrm{S}$ do ciclo celular na linhagem ReH. AZB foi capaz de desmetilar parcialmente o gene $A h R$ e reduzir a expressão dos genes $D N M T 1, D N M T 3 a$ e $D N M T 3 b$. Todos os dados encontrados no presente trabalho sugerem que as drogas desmetilantes podem ser interessantes agentes para o tratamento da LLA pediátrica. 


\title{
Ginecologia e Obstetrícia
}

\section{ESTUDO COMPARATIVO CONTROLADO E PROSPECTIVO DOS MARCADORES ULTRASSONOGRÁFICOS DE FUNÇÃO ENDOTELIAL DE CONTRACEPTIVOS CONTENDO 3OUG DE ETINILESTRADIOL COMBI- NADO A 2MG DECLORMADINONA OU 150 UG DE LEVONORGESTREL EM MULHERES HÍGIDAS}

\author{
Silvio Antonio Franceschini \\ Orientador: Prof. Dr. Rui Alberto Ferriani \\ Tese de Doutorado apresentada em 30/03/2012
}

Introdução: Já é bem conhecido o uso de contraceptivos orais combinados (COC) e o aumento do risco de desenvolvimento de eventos tromboembólicos arteriais e venosos, no entanto, são limitados os dados na literatura científica avaliando o impacto do COC na função do endotélio.

Objetivos: avaliar os efeitos endoteliais das associações $30 \mu \mathrm{g}$ de etinilestradiol (EE) e $2 \mathrm{mg}$ de Acetato de Clormadinona (CMA) e 30 $\mu$ g de EE e 150ug de Levonorgestrel (LNG) em mulheres hígidas usuárias desses COCs através dos marcadores ultrassonográficos: dilatação mediada por fluxo (FMD) da artéria braquial, espessura íntima média (IMT) da artéria carótida comum e índice de rigidez da artéria carótida comum $(\beta)$ e compará-los com um grupo controle.

Metodologia: O estudo clínico prospectivo envolveu 64 mulheres hígidas, 21 quiseram método contraceptivo não hormonal (controle) e 43 que optaram pelo uso de COC, sendo que 22 foram randomizadas para a associação EE $0,03 \mu \mathrm{g}$ e CMA $2 \mathrm{mg}$ e 21 para a associação EE $0,03 \mu \mathrm{g}$ eLNG $0,150 \mu \mathrm{g}$ por 06 meses. No tempo zero e aos 6 meses foram feitas medidas antropométricas, pressão arterial sistólica (PAS) e diastólica (PAD)e os seguintes marcadores ultrassonográficos de função endotelial: dilatação mediada por fluxo (FMD) da artéria braquial, espessura íntima média (IMT) da artéria carótida comum e índice de rigidez da artéria carótida comum $(\beta)$.

Resultados: As usuárias da associação EE/CMA apresentaram apenas uma queda significativa da PAD aos 6 meses com relação ao período basal ( $\mathrm{p}=0,02)$. Nas mulheres usuárias da associação EE/LNG, observou-se um aumento da medida da IMT aos 6 meses em relação ao período basal $(\mathrm{p}=0,02)$ e uma diminuição significativa na $\mathrm{DMF}$ em relação à medida basal $(\mathrm{p}=0,01)$, Aos 6 meses observa-se uma queda significativa da PAD nas usuárias de COC, em comparação ao grupo controle $(\mathrm{p}=0,01)$. Na avaliação intergrupos observou-se, aos 6 meses diminuição significativa na variação da DMF nas usuárias da associação EE/LNG em relação ao grupo controle $(\mathrm{p}=0,05)$, além disso, queda significativa da PAS no grupo das usuárias da associação $\mathrm{EE} / \mathrm{LNG}$, em relação ao grupo controle $(\mathrm{p}=0,02)$ e queda da PAD nas usuárias de ambos os COC em relação ao grupo controle (EE/CMA: $p<0,01$ e EE/LNG: $p=0,01$ ). Todas as demais variáveis clínicas e ecográficas não mostraram mudanças significativas na avaliação intergrupos.

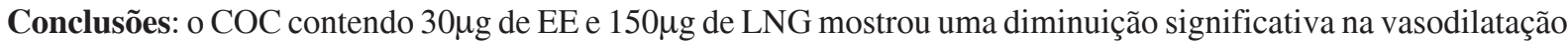
endotélio-dependente em mulheres hígidas com relação ao grupo controle. A associação contendo $30 \mu \mathrm{g}$ de EE e $2 \mathrm{mg}$ de CMA não mostrou alterações nessa vasodilatação das mulheres usuárias desse COC em relação ao grupo de mulheres controle. Esse fato pode significar um perfil desfavorável do LNG no endotélio de mulheres hígidas, em relação a outros progestogênios, como a CMA.

\section{Imunologia Básica e Aplicada}

\section{VACINA DE DNA MULTICOMPONENTE BASEADA EM GENES CODIFICANTES DE PROTEÍNAS SALIVARES DE Rhipicephalus microplus INDUZ IMUNIDADE CRUZADA CONTRA INFESTAÇÕES POR Rhipicephalus sanguineus EM CAMUNDONGOS E CÃES}

Elen Anatriello

Orientadora: Profa. Dra. Isabel Kinney Ferreira de Miranda Santos

Tese de Doutorado apresentada em 30/01/2012

Os carrapatos são artrópodes hematófagos, vetores de doenças. Vacinas são uma alternativa para seu controle, já que esses parasitas durante a infestação, estimulam as respostas imunes do hospedeiro, as quais são implicadas em sua rejeição. As glândulas salivares do parasita são importantes para permitir a alimentação e para mediar os mecanismos de escape às defesas do hospedeiro. Diversas evidências indicam que ocorre reatividade cruzada entre espécies de carrapa- 
tos e que reações de hipersensibilidade cutânea tardia (DTH) são correlacionadas com resistência ao carrapato. A possibilidade de vacinar cachorros que são parasitados pelo $R$. sanguineus com antígenos do carrapato do boi, o R. microplus, foi investigada por meio da análise in silico de 45 GIs de $R$. microplus clonados em vetor plasmidial (TOPO VR2001), dentre os quais 14 GIs de $R$. microplus se revelaram mais similares a sequências do $R$. sanguineus, e foram empregados para avaliar: 1) A capacidade em elicitar reações cutâneas tardias em cobaias imunes a carrapatos por meio de infestações prévias com $R$. sanguineus. 2) A capacidade de vacinas contendo GIs individuais em afetar infestações de camundongos com adultos de $R$. sanguineus. 3) a capacidade do GI induzir anticorpos específicos após vacinação em camundongos. Dos 14 GIs testados, apenas dois não induziram reações cutâneas, quatro não afetaram nenhum parâmetro parasitológico da infestação, e três não induziram a produção de anticorpos nesses animais. Dentre os GIs, sete foram escolhidos para compor uma vacina multigênica contra o carrapato do cão $R$. sanguineus. A vacina foi capaz de induzir resistência á infestação por $R$. sanguineus em camundongos e em cachorros vacinados evidenciadoa pela diminuição do número de fêmeas que conseguiram colocar ovos, do peso médio da massa de ovos produzidos por essas fêmeas, do índice reprodutivo dessas fêmeas, e da taxa de eclosão das larvas, demonstrando que GIs de $R$. microplus podem ser alvos para formulação de uma vacina contra o carrapato $R$. sanguineus.

\title{
PAPEL DE LINFÓCICOS TH17 DURANTE A INFECÇÃO EXPERIMENTAL POR Leishmania infantum/chagasi
}

\author{
Manuela Sales Lima Nascimento
}

Orientador: Prof. Dr. João Santana da Silva

Dissertação de Mestrado apresentada em 16/02/2012

Leishmaniose visceral (LV) é uma doença crônica e potencialmente fatal causada pelas espécies Leishmania infantum/ chagasi e Leishmania donovani. O desenvolvimento da resposta Th1 é classicamente associado à proteção contra esses parasitos, mas também há uma correlação positiva entre a produção de citocinas relacionadas com o padrão Th17 e a proteção contra LV por L. donovani em seres humanos. No entanto, a participação de Th17 durante a infecção por $L$. infantum/chagasi permanece desconhecida. O objetivo desse estudo foi avaliar a participação de Th17 e citocinas relacionadas, além do mecanismo pelo qual tais células operam durante a resposta imune do hospedeiro contra $L$. infantum/ chagasi. Os resultados mostraram que o parasito é capaz de induzir grandes quantidades de TGF- $\beta$, IL- $1 \beta$, IL-6 e IL- 23 por células dendríticas derivadas da medula óssea (BMDC), citocinas envolvidas na indução e/ou manutenção do perfil Th17. Assim, co-cultivando células do baço de camundongos C57BL/6 naúves com BMDCs infectadas com L. infantum/chagasi observou-se uma significativa produção de IL-17 por células T. Esses achados foram confirmados por experimentos in vivo onde se constatou a produção de IL-17 no fígado e no baço de camundongos WT infectados, sendo o pico de produção dessa citocina observado na $4^{\mathrm{a}}$ e $6^{\mathrm{a}}$ semanas após a infecção. O padrão de resposta do tipo Th17 é crítica para a imunidade protetora contra $L$. infantum/chagasi, uma vez que camudongos IL-17R ${ }^{-1}$, IL-23p19-- e IL-6 $6^{-/}$mostraram aumento da carga parasitária nos órgãos alvo da infecção, sendo que a susceptibilidade observada em camundongos IL$17 \mathrm{R}^{-/-}$foi associada com o aumento da produção de IL-10 por linfócitos, sugerindo que a IL-17 regula negativamente a produção de IL-10 levando ao controle da infecção causada pelo parasito. Ainda, a ausência da sinalização via IL-17R gerou uma diminuição da inflamação hepática, decorrente de uma menor capacidade proliferativa de linfócitos frente ao estímulo com conA. De maneira interessante, na ausência de IL-10 houve potencialização na produção de IL-17 por camundongos infectados, e esses foram mais resistentes à infecção, apresentando números reduzidos parasitos no baço e no fígado. Além de promover proteção através da modulação de IL-10, a IL-17 foi capaz de potencializar a produção de NO in vitro e in vivo. Juntos, nossos resultados demonstram que a L. infantum/chagasi é capaz de desencadear o padrão Th17 de resposta imune, o qual promove proteção do hospedeiro durante a infecção.

\section{O PAPEL DOS MICRORNAS DE CÉLULAS T NA SUSCEPTIBILIDADE/RESISTÊNCIA A ARTRITE REUMATÓIDE EXPERIMENTAL}

\section{Paula Barbim Donate Yabuta}

Orientador: Prof. Dr. Geraldo Aleixo da Silva Passos Junior

Tese de Doutorado apresentada em 01/03/2012

Os microRNAs são pequenos RNAs, não-codificantes que funcionam como reguladores a nível pós-transcricional da expressão gênica. Nos últimos anos, novas evidências demonstram o papel importante dos microRNAs na regulação e 
desenvolvimento do sistema imune. Apesar da função de poucos microRNAs ser conhecida, a sua expressão alterada vêm sendo associada a patogênese de diversas doenças autoimunes, incluindo a artrite reumatóide (AR). Recentemente a expressão desregulada de uma série de microRNAs está sendo descrita em pacientes com AR, e o papel patogênico de apenas uma parte deles foi investigada em modelos animais. A artrite reumatóide é uma doença autoimune sistêmica caracterizada por um intenso processo inflamatório na sinóvia, podendo causar destruição óssea e articular. Os linfócitos T apresentam papel importante na indução, manutenção e progressão da doença. A artrite induzida por colágeno é um modelo animal amplamente utilizado por suas características fisiopatológicas muito similares à doença em humanos. A linhagem de camundongos DBA-1/J desenvolve a doença após imunização e booster com colágeno do tipo II, enquanto que a linhagem DBA-2/J se mostra refratária. Isso confere um sistema modelo de susceptibilidade/resistência à artrite, que pode ser estudado em diferentes abordagens. O objetivo do nosso estudo foi identificar o perfil transcricional e as redes de interação entre um grupo de microRNAs e seus respectivos alvos nos timócitos e linfócitos T CD3+ periféricos nos camundongos da linhagem DBA-1/J e DBA-2/J. Para a avaliação da expressão gênica, utilizou-se a tecnologia de microarrays. O uso de programas de análise e para a construção das redes foi imprescindível. Os resultados encontrados evidenciam uma expressão diferenciada de mRNAs e microRNAs em timócitos e linfócitos T CD3 ${ }^{+}$periféricos entre as duas linhagens utilizadas. Novos microRNAs foram encontrados nos diferentes estágios de desenvolvimento do linfócito T. Nas redes de interação microRNA-RNAm obtidas, genes importantes associados aos processos de sistema imune, adesão e diferenciação celular, apoptose, recombinação, ativação de linfócitos T e resposta inflamatória, foram encontrados como potenciais alvos. Além disso, em uma perspectiva clínica, baseados nos resultados obtidos em camundongo, nos encontramos a expressão do miR-505 nos linfócitos T de pacientes com AR. Nossos resultados contribuem para a melhor compreensão dos mecanismos molecular envolvidos na resistência/susceptibilidade a CIA.

\title{
ANTÍGENOS SALIVARES RECOMBINANTES DE Rhipicephalus microplus SELECIONADOS POR IMUNOVACINOLOGIA REVERSA: EFEITO DA VACINAÇÃO DE BOVINOS NO CONTROLE DAS INFESTAÇÕES POR CARRAPATOS
}

\author{
Sandra Regina Costa Maruyama \\ Orientadora: Prof ${ }^{a}$. Dr ${ }^{\text {a }}$. Isabel Kinney Ferreira de Miranda Santos \\ Tese de Doutorado apresentada em 29/03/2012
}

Rhipicephalus microplus, o carrapato dos bovinos, causa enormes prejuízos à saúde animal e ao setor pecuário. Por induzirem resposta imunológica em seus hospedeiros, o controle imunobiológico é possível. Entretanto, as vacinas disponíveis no mercado apresentam eficácia variável e pouco duradoura. O estudo da expressão de genes importantes no contexto do parasitismo associado ao perfil de imunidade do hospedeiro pode indicar antígenos protetores úteis para compor uma vacina anticarrapato. Essa abordagem, utilizada neste trabalho, foi denominada Imunovacinologia Reversa. Deste modo, este trabalho teve como objetivo geral obter antígenos salivares recombinantes de $R$. microplus, selecionados através da estratégia de Imunovacinologia Reversa, para testá-los como antígenos candidatos a uma vacina anticarrapato. Para isso, os transcritos de glândulas salivares e larvas de $R$. microplus foram analisados por ferramentas de bioinformática e as sequências dos genes subclonadas em vetor pET100/D-TOPO para a expressão das proteínas recombinantes. Dos oito genes selecionados, três antígenos salivares recombinantes foram eficientemente produzidos, os quais foram denominados Rm39, Rm180 e Rm239. A presença dessas proteínas em $R$. microplus alimentados em hospedeiro geneticamente resistente (raça Nelore) ou suscetível (raça Holandesa) foi avaliada empregando extratos de glândulas salivares/larvas e anticorpos policlonais IgY. De maneira semelhante aos dados do transcriptoma, essas proteínas também foram diferencialmente expressas, dependendo de qual hospedeiro o carrapato se alimentou. Quando testado se soros de bovinos infestados reconheciam estas proteínas, embora esses antígenos fossem salivares, os soros reconheceram os antígenos recombinantes Rm39 e Rm180 somente a partir da terceira e sexta infestação, respectivamente. A Rm239 recombinante não foi reconhecida por nenhum soro avaliado. Em seguida as proteínas Rm39, Rm180 e Rm239 recombinantes foram testadas como vacina anticarrapato multicomponente, adicionada a um quarto antígeno salivar recombinante, Rm76. Após a imunização de bezerras geneticamente suscetíveis, elas foram desafiadas com larvas de $R$. microplus e foi observado uma redução significante no número de carrapatos $(52,5 \%)$ e no peso de ingurgitamento $(55,2 \%)$ no grupo imunizado comparado ao grupo controle. Os cálculos de eficácia da vacinação baseados nos parâmetros biológicos da infestação desafio nos bovinos imunizados mostraram uma eficácia da vacina de 73,2\%. Na avaliação da produção de anticorpos antígeno-específicos, antes, durante as imunizações e após a infestação, apenas os antígenos Rm76 e Rm239 estimularam a produção predominante de IgG1 antígeno-específicas e de IgG2 antígeno-específicas em baixas quantidades. Esses 
resultados sugerem que a resposta imunológica de memória foi adequadamente estimulada com os antígenos da saliva expostos durante a picada do carrapato. A imunização com os antígenos salivares recombinantes Rm39 e Rm180 estimulou um repertório menor de IgG1 antígeno-específicas. Além disso, a resposta de IgG1 antígeno-específica para esses dois antígenos não foi re-estimulada durante a infestação. Mesmo com antígenos apresentando diferentes níveis de indução de resposta de anticorpo, a vacina anticarrapato multicomponente testada neste trabalho apresentou bom nível de proteção em bovinos geneticamente suscetíveis. De modo geral, a abordagem de Imunovacinologia Reversa mostrou-se promissora na identificação de novos antígenos vacinais.

\title{
Neurologia
}

\section{CARACTERIZAÇÃO NEUROETOLÓGICA DE CRISES EPILÉPTICAS DE PACIENTES COM EPILEPSIA DO LOBO FRONTAL (ELF)}

\author{
Poliana Bertti Dutra \\ Orientador: Prof. Dr. Norberto Garcia Cairasco \\ Tese de Doutorado apresentada em 25/01/2012
}

Em humanos, para o melhor entendimento da Epilepsia do Lobo Temporal (ELT), a Neuroetologia foi desenvolvida num grupo de pacientes com ELT mesial unilateral (Dal-Cól et al, 2006) e em seguida, associada a Tomografia Computadorizada por Emissão de Fóton Único (SPECT) (Bertti et al, 2010). Enquanto as ELT mesiais foram extensivamente descritas, as ELF ainda representam um desafio para o entendimento de como as crises se originam e também para o tratamento. Em frequência, o segundo maior sítio de anormalidades neurofisiológicas causadoras de crises epilépticas é o lobo frontal. A avaliação dos dados eletrofisiológicos, de neuroimagem e semiológicos são fundamentais nos casos de ELF refratários ao tratamento farmacológico, mas cirurgicamente tratáveis, tanto para localizar de maneira precisa o tecido a ser removido quanto avaliar o prognóstico do paciente após a cirurgia.

Objetivo: O objetivo do presente estudo é aplicar a análise neuroetológica às crises epilépticas originadas no lobo frontal, identificar a existência de padrões semiológicos e verificar semelhanças ou diferenças entre os padrões encontrados nas crises de ELF.

Métodos: Análise comportamental foi desenvolvida em 18 pacientes com ELF através da soma de crises por paciente previamente à lobectomia ou lesionectomia frontal; todos com Engel I após a cirurgia. Os registros de video-EEG foram realizados no Centro de Cirurgia em Epilepsia (CIREP) do HC-FMRP-USP. Os vídeos foram digitalizados e os comportamentos ictais anotados segundo-a-segundo. Os dados foram analisados utilizando o programa estatístico ETHOMATIC e apresentados em fluxogramas incluindo frequência, duração, e interação sequencial entre comportamentos.

Resultados: Foram analisadas 120 crises de 18 pacientes, 13 do sexo masculino e 5 do sexo feminino. Dados bem estabelecidos na literatura foram confirmados, como a associação com o sono e a rápida recuperação pós-ictal. Foram observadas crises hipermotoras ou parciais complexas de origem no lobo frontal, crises versivas, crises clônicas focais e crises tônicas (área motora suplementar). Nos fluxogramas, representação gráfica das sequências comportamentais, os eventos motores complexos, a versão da cabeça e dos olhos, a postura tônica uni ou bilateral, automatismos oroalimentares, o comprometimento da fala e diversas maneiras de vocalização foram identificados com duração e frequência elevados e por vezes contribuíram para fins de lateralização ou localização do foco. Desvio cefálico e facial wiping postictal também estavam presentes, mas sem valor lateralizatório. As associações estatisticamente significativas entre pares de comportamentos (díades) e as novas sequências comportamentais observadas em ELF foram sugestivas também da eventual propagação das crises.

Conclusão: A Neuroetologia das crises do lobo frontal permitiu a detecção de tipos semiológicos e de comportamentos com valores localizatórios e lateralizatórios, corroborando dados previamente descritos na literatura, representando uma ferramenta adicional para o estudo das eventuais vias de propagação das crises frontais pela semiologia. Terá impacto futuro ao considerarmos, por exemplo, a associação com exames de EEG ou imagem, ou ainda quando aplicada também a outras patologias cerebrais. 


\title{
ANÁLISE ESTRUTURAL, QUALITATIVA E QUANTITATIVA, DO NERVO FRÊNICO NA HIPERTENSÃO ESPONTÂNEA EM RATOS: COMPARAÇÃO ENTRE GÊNEROS E DIFERENTES FASES DO DESENVOLVIMENTO
}

\author{
Anaceres Ribeiro Rodrigues
}

Orientador: Prof. Dr. Valeria Paula Sassoli Fazan

Tese de Doutorado apresentada em 14/03/2012

É bem conhecido que o envelhecimento afeta a função, a morfologia e a morfometria do nervo periférico. Nós registramos anteriormente importantes diferenças na morfologia do nervo frênico entre ratos adultos normotensos e espontaneamente hipertensos (SHR). No presente estudo nós investigamos como a associação entre envelhecimento e hipertensão afeta a morfometria desse nervo. Fêmeas e machos SHR com idades de 5, 8, 20, 40 e 50 semanas (n=6 por grupo) foram anestesiados para registro da pressão arterial (PA) e freqüência cardíaca (FC). Os segmentos proximal e distal dos nervos frênicos direito e esquerdo foram removidos e preparados para inclusão em resina epóxi e morfometria em microscopia de luz.

O peso corporal foi significativamente maior nos machos, enquanto as pressões sistólica, diastólica e média, foram maiores e continuaram a aumentar significativamente com a idade nas fêmeas. Os nervos frênicos, em machos e fêmeas, mostraram simetria morfométrica lateral e longitudinal para ambos os grupos jovens ( 5 e 8 semanas) mas tornaram-se assimétricos lateral e longitudinalmente com o envelhecimento, sendo o segmento distal esquerdo geralmente menor que os segmentos proximal esquerdo e distal direito. Aárea fascicular foi semelhante entre os animais de 5 e 8 semanas de idade e continuou a aumentar significativamente com o envelhecimento, seguindo o peso corporal. O número de fibras mielínicas foi constante nas diferentes idades, mas a densidade das fibras mielínicas diminuiu com o envelhecimento. O tamanho da fibra mielínica aumentou com o envelhecimento, sendo semelhante nas idades de 40 e 50 semanas. Entretanto, nas fêmeas, o tamanho do axônio diminuiu de 40 para 50 semanas de idade, indicando uma possível atrofia axonal devido à hipertensão. Como esperado, o envelhecimento afetou o tamanho dos fascículos e das fibras mielínicas sem nenhuma alteração no número de fibras. Além disso, o desenvolvimento da hipertensão afetou os parâmetros morfológicos considerados importantes para a função das fibras mielínicas.

\section{USO DO PADRÃO ICTAL NA EPILEPSIA DA REGIÃO MESIAL DO LOBO TEMPORAL ASSOCIADA À ESCLEROSE HIPOCAMPAL COMO MARCADOR PROGNÓSTICO PÓS-CIRÚRGICO: UMA COORTE RETROSPECTIVA}

\author{
Bruno Zanotelli Monnerat \\ Orientador: Prof. Dr. Américo Ceiki Sakamoto \\ Dissertação de Mestrado apresentada em 29/03/2012
}

Pacientes com epilepsia do lobo temporal farmacorresistente, frequentemente, possuem esclerose hipocampal como lesão epileptogênica. Muitas vezes, estes pacientes se beneficiam de lobectomia temporal para redução da ocorrência de crises epilépticas. Para que possam se submeter a este procedimento, é necessário o uso da videoeletroencefalografia prolongada para delimitação apurada da zona epileptogênica. Apesar dos avanços dos métodos diagnósticos nesta área, a busca por um instrumento que permita uma avaliação clara da chance de uma vida livre de crises após cirurgia permanece. No presente trabalho, a apresentação do padrão eletroencefalográfico ictal foi estudado, de forma a se pesquisar se existe relação entre a sua ocorrência e permanência em apenas um hemisfério cerebral com um melhor prognóstico pós-cirúrgico. Foram revisados os dados eletroencefalográficos ictais e os prontuários médicos de 284 pacientes. Procedeu-se à classificação de seus padrões eletroencefalográficos ictais em unilaterais ou bilaterais, e seu prognóstico após um, dois e cinco anos após cirurgia em livre de crise ou não livre de crise epiléptica. Apresentavam padrão unilateral 132 pacientes, e 152 apresentavam padrão bilateral. Estavam livres de crises 236 pacientes, e 48 ainda persistiam com crises epilépticas após cirurgia. Não houve associação entre padrões ictais unilaterais e uma vida livre de crises epilépticas após a cirurgia (diferença de 7,5\%; $\mathrm{p}=0,092$; chiquadrado).

Dessa forma, não se pode aplicar o padrão ictal eletroencefalográfico como ferramenta para predição de uma vida livre de crises após lobectomia temporal em pacientes com epilepsia da região mesial do lobo temporal associada à esclerose hipocampal. 


\title{
Oftalmologia, Otorrinolaringologia e Cirurgia de Cabeça e Pescoço
}

\author{
ESFERAS DE POLIMETILMETACRILATO MULTIPERFURADAS COMO MODELO \\ DE IMPLANTE ORBITÁRIO INTEGRÁVEL - ESTUDO EXPERIMENTAL
}

\author{
Denise Myiashita \\ Orientador: Prof. Dr. Antonio Augusto Velasco e Cruz \\ Tese de Doutorado apresentada em 27/01/2012
}

O objetivo do estudo foi avaliar a estrutura de um implante orbitário comercial de polimetilmetacrilato (PMMA) multiperfurado, bem como sua resposta clínica e tecidual em modelo animal. Dezesseis coelhos da raça Nova Zelândia receberam, após evisceração do globo ocular com esclerotomia posterior, o implante de PMMA multiperfurado, de diâmetro $12 \mathrm{ou} 13 \mathrm{~mm}$. Foi realizada avaliação clínica diária nos primeiros 14 dias, e depois, a cada sete dias até o fim do período do estudo (180 dias). Para análise histopatológica, quatro animais por grupo foram submetidos à exenteração da órbita aos $14,45,90$ e 180 dias e depois sacrificados. Foi realizada coloração por hematoxilina-eosina e picrosirius red para avaliação do padrão inflamatório e de formação de colágeno. A microarquitetura do implante caracterizou-se pela presença de canais interligados pelo centro. Não houve sinais de infecção, exposição ou extrusão do implante em nenhum animal no período estudado. Ocorreu crescimento de tecido fibrovascular através dos canais formados e no seu centro a partir do $14^{\circ}$ dia, com crescente aumento até os 180 dias. A quantidade de resposta inflamatória foi inversamente proporcional ao crescimento fibrovascular. Não foram encontradas células gigantes multinucleadas. O implante multiperfurado é inerte e biocompatível, além ser totalmente integrável à órbita, por meio de crescimento de tecido fibrovascular no interior do implante semelhante aos modelos integráveis.

\section{ANÁLISE DO EFEITO DA TERAPIA MIOFUNCIONAL OROFACIAL ASSOCIADA A LASERTERAPIA EM PACIENTES COM DESORDEM TEMPOROMANDIBULAR}

\author{
Bárbara Cristina Zanandréa \\ Orientadora: Profa. Dra. Cláudia Maria de Felício \\ Dissertação de Mestrado apresentada em 30/01/2012
}

Introdução: A desordens temporomandibulares (DTMs) abrangem uma série de problemas clínicos que envolvem a musculatura mastigatória, a própria articulação e estruturas associadas. Os efeitos da laserterapia em casos de DTM veem sendo estudados como modalidade única de tratamento ou associada à outras terapias, contudo não há qualquer estudo sobre a associação da laserterapia à terapia miofuncional orofacial (TMO).

Objetivo: avaliar a eficácia terapêutica da TMO modificada pela substituição das estratégias convencionais para alívio da dor pela laserterapia (terapia modificada associada a laserterapia $=\mathrm{Tm}-\mathrm{L}$ ), comparativamente à TMO e terapia modificada associada ao laser placebo (Tm-LP)

Método: Participaram 60 pacientes com DTM, diagnosticados de acordo com o Research Diagnostic Criteria for Temporomandibular Disorders (RDC/TMD) e divididos aleatoriamente em três grupos de tratamento. Um grupo (grupo T) realizou TMO, de acordo com protocolo previamente testado; os outros dois grupos receberam laserterapia e TMO, modificada pela substituição das técnicas de alívio da dor, sendo que para um deles o laser era, de fato, ativo (Tm-L) e para o outro inativo, funcionando como placebo (Tm-LP). Tanto os pacientes como o profissional desconheciam qual era a modalidade de laser (duplo-cego). As medidas de resultados foram: Índices Anamnésico e de Disfunção Clínica de Helkimo, limiar de dor a palpação (algometria), percepção de severidade dos sinais e sintomas de DTM e avaliação miofuncional orofacial. As comparações incluíram os dados dos três grupos nas fases diagnóstica (FD), final de tratamento (FF), seguimento depois de um mês (FS1) e depois de três meses da conclusão do tratamento (FS3), por meio de múltipla análise de variância, com efeitos fixos (three-way Anova). O pós-teste Tukey foi aplicado para diferenças significantes. O nível de significância estabelecido foi de $5 \%(P<0,05)$.

Resultados: Ao final do tratamento, os grupos T, Tm-L e Tm-LP apresentaram melhora de todos os parâmetros avaliados. Houve diferença entre os grupos apenas para os movimentos excursivos da mandíbula, onde o pós teste indicou diferença entre os grupos Tm-L e T, devido maior média geral no grupo T. Além disso, houve diferença entre as fases para a sensibilidade dolorosa à palpação, limiar de dor à pressão, severidade dos sinais e sintomas de DTM e condição miofuncional orofacial, sendo a Fase D significantemente diferente das fases FF, FS1 e FS3. 
Conclusão: A TMO modificada pela substituição das estratégias convencionais para alívio da dor pela laserterapia não foi mais eficaz para os casos de DTM que o programa completo de TMO ou TMO modificada e associado ao laser placebo.

\title{
BEVACIZUMABE INTRAVÍTREO PARA RETINOPATIA DIABÉTICA COM NEOVASCULARIZAÇÃO DE RETINA PERSISTENTE
}

\author{
Léssia de Pedro Cintra Ferrara \\ Orientador: Prof. Dr. Rodrigo Jorge \\ Tese de Doutorado apresentada em 27/02/2012
}

Objetivo: Avaliar os efeitos na Acuidade Visual e Angiografia Fluoresceínica de injeções de bevacizumabe intravítreo (IV) no tratamento de neovasos (NV) persistentes associados à retinopatia diabética (RD).

Desenho do estudo: Estudo prospectivo, não randomizado, aberto.

Métodos: Pacientes diabéticos com vazamento ativo de NV refratários a tratamento com laser e com melhor Acuidade Visual corrigida (MAVC) em LogMAR (ETDRS) de 0,3 (equivalente de Snellen 20/40) ou inferior. Avaliação oftalmológica incluindo angiografia fluoresceínica foi realizada na visita basal e nas semanas 1, 6, 12, 24 e 48 ( \pm 1 ), após injeção intravítrea de 1,5 mg de bevacizumabe. Após a semana 12, os pacientes foram retratados com nova injeção intravítrea de $1,5 \mathrm{mg}$ de bevacizumabe caso o médico julgasse necessário (Pro re nata, PRN). Os principais parâmetros estudados foram: modificações na área total de vazamento fluoresceínico de NV ativos e MAVC.

Resultados: Quinze pacientes, oito homens (53\%) e sete mulheres (47\%) foram incluídos, mas somente doze completaram as 48 semanas de acompanhamento do estudo. A média \pm desvio-padrão (DP) de idade dos participantes foi

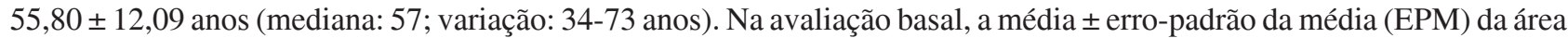
de vazamento do NV foi 27,79 $\pm 6,29 \mathrm{~mm}^{2}$. A média \pm EPM da área de vazamento ativo de NV diminuiu significativamente para 5,43 $\pm 2,18 \mathrm{~mm}^{2}, 5,50 \pm 1,24 \mathrm{~mm}^{2}, 9,97 \pm 3,22 \mathrm{~mm}^{2}, 3,12 \pm 1,33 \mathrm{~mm}^{2}$, nas semanas $1(\mathrm{p}=0,0001), 12(\mathrm{p}=0,0001), 24(\mathrm{p}=0,0083)$ e 48 ( $\mathrm{p}=0,0007$ ), pós injeção, respectivamente; na semana 6, nenhum vazamento foi observado ( $\mathrm{p}=0,0001)$. A média \pm EPM LogMAR (equivalente de Snellen) da MAVC melhorou significativamente de $0,90(20 / 160) \pm 0,11$ no basal para 0,76 (20/ $\left.125^{+2}\right) \pm 0,12,0,77\left(20 / 125^{+2}\right) \pm 0,11,0,77\left(20 / 125^{+2}\right) \pm 0,12,0,74\left(20 / 100^{-2}\right) \pm 0,13$ e $0,70(20 / 100) \pm 0,12$ nas semanas 1 $(\mathrm{p}=0,0010), 6(\mathrm{p}=0,0020), 12(\mathrm{p}=0,0018), 24(\mathrm{p}=0,0249)$ e $48(\mathrm{p}=0,0449)$, respectivamente. Foi necessária média de 2,16 injeções em cada paciente que completou as 48 semanas. Nenhum evento desfavorável foi observado.

Conclusões: Repetidas aplicações de $1,5 \mathrm{mg}$ de bevacizumabe IV em pacientes com RD resultaram na redução do vazamento de fluoresceína de NV ativos persistentes e na melhora da acuidade visual.

\section{MEMÓRIA DE TRABALHO, COMPREENSÃO DE LEITURA E ARITMÉTICA EM CRIANÇAS RESPIRADORAS ORAIS}

\author{
Rita Cristina Sadako Kuroishi \\ Orientadora: Profa. Dra. Marisa Tomoe Hebihara Fukuda \\ Dissertação de Mestrado apresentada em 29/02/2012
}

O padrão compensatório de Respiração Oral decorrente da obstrução das vias aéreas superiores pode desencadear uma série de alterações ao organismo das crianças, e consequentemente prejudicar habilidades cognitivas, necessárias para o rendimento escolar satisfatório. O objetivo do presente trabalho foi estudar o desempenho de crianças diagnosticadas como respiradores orais em tarefas de memória de trabalho fonológica, de compreensão de leitura e de resolução aritmética e investigar a inter-relação entre a memória de trabalho fonológica e compreensão de leitura e aritmética.

Método: Participaram 54 escolares de ambos os sexos, entre 7 e 10 anos de idade, divididos em dois grupos de acordo com o diagnóstico da avaliação otorrinolaringológica: Grupo Controle, denominado de G1 (n=13), composto por crianças respiradoras nasais e G2 $(n=41)$, composto por crianças portadoras de respiração oral. As crianças de ambos os grupos foram submetidas a uma audiometria tonal para excluir possíveis déficits auditivos, à avaliação otorrinolaringológica e à avaliação das habilidades de Memória de Trabalho Fonológica (MTF), de compreensão de leitura e desempenho em tarefa de aritmética. Para a avaliação das habilidades cognitivas foram utilizados os seguintes testes: Prova de Repetição de Palavras Sem Significado e Subteste 5, Memória Sequencial Auditiva, do Teste Illinois de Habilidades Psicolinguísticas (ITPA) para a avaliação da MTF, Teste de Competência da Leitura de Sentenças (TCLS 1.1) e subteste de aritmética do 
Teste de Desempenho Escolar (TDE). Para inferência estatística, utilizou-se os testes Mann-Whitney, Manova com medidas repetidas, teste de correlação de Spearman, com nível de significância $\mathrm{p} \leq 0,05$.

Resultados: G1 obteve valores de pontuação estatisticamente maiores no teste de compreensão de sentenças e de resolução aritmética em relação ao G2. Quanto à MTF, os grupos se diferiram somente na prova de repetição de palavras sem significado. Observou-se correlação positiva da MTF (Repetição de palavras sem significado) com a compreensão de leitura e com a aritmética, e a repetição de dígitos esteve correlacionada positivamente somente com a aritmética.

Conclusões: Ser respirador oral é uma condição de risco para o bom desempenho escolar em crianças. Crianças respiradoras orais apresentaram desempenho inferior em testes de MTF, de compreensão de leitura e de aritmética em relação às crianças respiradoras nasais. A MTF apresenta forte relação com compreensão de leitura e aritmética.

\title{
MORFOLOGIA E FUNÇÃO DAS CÉLULAS ACINARES EM CULTURA PRIMÁRIA DE GLÂNDULA LACRIMAL
}

\author{
Leonardo Tannus Malki \\ Orientador: Prof. Dr. Eduardo Melani Rocha \\ Dissertação de Mestrado apresentada em 02/03/2012
}

Objetivo: As células acinares possuem papel fundamental na produção e liberação da lágrima. Em estudos prévios, foi observada a insulina na secreção lacrimal e a presença desse hormônio chave para o funcionamento da glândula lacrimal e manutenção de uma boa superfície ocular. O objetivo é estabelecer uma linhagem de cultura de células acinares de glândula lacrimal, promover variações das condições de cultivo, estímulos secretórios positivos e negativos para avaliar o efeito na secreção de insulina e outras substâncias presentes na lágrima.

Métodos: Células acinares foram isoladas a partir de glândulas lacrimais de ratos machos wistar e submetidas à cultura celular para avaliação da viabilidade, do número celular e da liberação de peroxidases a partir de modificações realizadas no meio de cultura, além da avaliação do comportamento e das respostas celulares mediante estimulação com carbacol.

Resultados: Houve um aumento na liberação de peroxidase em reposta ao estímulo com carbacol. Elevação na concentração de insulina adicionada ao meio de cultura resulta em melhor viabilidade e maior liberação de peroxidase comparativamente ao meio com privação deste hormônio.

Conclusões: A insulina influencia de modo estratégico no comportamento da célula acinar. Ambientes com deficiência de insulina resultam em piora dos parâmetros comportamentais deste tipo celular em cultura. Os dados apresentados confirmam a importância da insulina como hormônio chave na manutenção do componente aquoso da lágrima.

\section{MECANISMO DE SECREÇÃO DA GLÂNDULA LACRIMAL DE RATOS DIABÉTICOS E A RESPOSTA À REPOSIÇÃO DE INSULINA}

\author{
Ana Carolina Dias \\ Orientador: Prof. Dr. Eduardo Melani Rocha \\ Tese de Doutorado apresentada em 02/03/2012
}

Em glândulas lacrimais (GL), agonistas colinérgicos transmitem sinais que regulam a liberação de produtos secretórios e estes eventos são governados no citoplasma por grupos de proteínas conhecidas como Rab e SNARE. O objetivo do presente estudo foi comparar a expressão do aparato secretório em glândulas lacrimais de ratos controles e diabéticos e o efeito da reposição de insulina. Diabetes mellitus foi induzido em ratos Wistar machos com streptozotocina intravenosa ou veículo e um subgrupo foi tratado em dias alternados com insulina. Após 10 semanas, GL dos três grupos (n=5/grupo/ procedimento experimental) tiveram a estrutura comparada e analisada a expressão de acetilcolina (Ach). Western blot e RT-PCR foram usados para comparar a expressão dos fatores secretórios de Rab e SNARE. Após 10 semanas de diabetes, não foi observado diferenças significativas nos níveis de Ach na GL entre os três grupos. Vesículas alargadas e número reduzido de grânulos secretórios (escuros) foram observados na GL do grupo de ratos diabéticos na microscopia eletrônica de transmissão, e eles foram em parte preservados no grupo de ratos tratados com insulina. A expressão de RNAm de Rab 3, Rab 27b, Rab 23 e Vamp2 não revelou mudanças no grupo de ratos diabéticos nem no grupo tratado com insulina. A análise por western blot demonstrou que proteínas Rab 27b, Rab 3, Sintaxina e Vamp2 foram significativamente reduzidas na GL de DM comparados aos controles $(\mathrm{p}<0,05)$. O tratamento com insulina aumentou a expressão de Rab 27b, Sintaxina e Rab 3 para os níveis dos animais controles, por outro lado a expressão de Vamp 2 em animais diabéticos foi 
diminuída mas não foi recompensada com o tratamento com insulina. As alterações na estrutura e função da GL em DM se somaram a redução na expressão de proteínas dos mecanismos exocitóticos revelando uma regulação pós- transcricional em GL de diabéticos. Estes eventos foram em parte prevenidos pela reposição de insulina, via mecanismos de ação diretos sobre as células acinares ou secundários envolvendo o controle de glicemia.

\title{
EFICÁCIA E SEGURANÇA DA Â-TERAPIA ADJUVANTE PÓS- RESSECÇÃO DE PTERÍGIO: ENSAIO CLÍNICO ALEATORIZADO COM METANÁLISE
}

\author{
Gustavo Viani Arruda
}

Orientador: Prof. Dr. Eduardo Melani Rocha

Tese de Doutorado apresentada em 02/03/2012

Objetivo: Avaliar a efetividade e segurança da beta-terapia ( $\beta$-terapia) pós-operatória em dose baixa e única comparando cirurgia de autoenxerto conjuntival com cirurgia de autoenxerto mais â-terapia adjuvante.

Métodos: Este estudo foi desenhado como um ensaio clínico aleatorizado (ECR) e metanálise. No ensaio clínico, a cirurgia foi realizada utilizando a técnica do autoenxerto conjuntival. Cento e oito pterígios foram operados e aleatorizados para cirurgia ou cirurgia mais $\beta$-terapia. No caso de $\beta$-terapia, um aplicador oftalmológico foi usado para dar uma dose única de 10 Gray (Gy). Após o tratamento, os pacientes foram acompanhados pelo oftalmologista e radio-oncologista. Além disso, uma metanálise de ECRs foi realizada para comparar as cirurgias com ou sem â-terapia.

Resultados: Entre fevereiro e setembro de 2008, 116 olhos com pterígio primário foram operados segundo o protocolo do estudo. O tratamento adjuvante foi realizado 24 horas após a cirurgia. Oito pacientes descontinuaram o seguimento, resultando em 108 pacientes que completaram o estudo. Com seguimento mediano de 18 meses (variando de 8-33), em 54 olhos aleatorizados para receberem cirurgia de autoenxerto e $\beta$-terapia, ocorreram cinco recorrências comparadas com doze em 54 olhos do grupo de cirurgia, com taxa de controle de $90.8 \%$ vs. $78 \%, p=0.032$, respectivamente. As complicacões do tratamento como hyperemia, deiscência do enxerto e dellen foram mais frequentes no grupo de cirurgia exclusiva ( $\mathrm{p}<0.05$ ). O braço de $\beta$-terapia resultou em melhores resultados cosméticos e redução dos sintomas, do que o braço de cirurgia exclusiva. A metanálise de seis ECRs foi combinada, demonstrando que a â-terapia foi mais efetiva do que apenas a cirurgia para evitar a recorrência da doença $(\mathrm{p}<0.00001)$. A $\beta$-terapia adjuvante mostrou similar controle da doença, quando comparada à Mitomicina-C $(\mathrm{MMC})(\beta$-terapia $=16 / 87=18.3 \%$ vs $\mathrm{MMC}=14 / 135=10.3 \%, \mathrm{p}=0.08)$. Avaliando o tipo de cirurgia, a $\beta$-terapia reduziu o risco de recorrência, independentemente do tipo de cirurgia (esclera nua $=7 / 62=11.2 \%$ vs $45 / 64=70.3 \%, \mathrm{p}<0.00001$ ou autoenxerto $=6 / 70=8.5 \%$ vs $16 / 78=20.5 \%, \mathrm{p}=0.04$ ); além disso, mostrou menos eventos adversos do que a MMC (2\% vs $5 \%)$.

Conclusão: A $\beta$-terapia em dose única e baixa de $10 \mathrm{~Gy}$ após a cirurgia de autoenxerto conjuntival foi um simples, efetivo e seguro tratamento, que reduziu o risco de recorrência do pterígio e os sintomas pós-operatórios, com melhores resultados cosméticos do que a cirurgia de autoenxerto. Esta metanálise também evidenciou que a â-terapia reduz o risco de recorrência do pterígio, independentemente do tipo de cirurgia (esclera nua ou autoenxerto) e produz controle similar da doença, com poucos efeitos colaterais, quando comparada com a MMC.

\section{AVALIAÇÃO ELETROMIOGRÁFICA DA MUSCULATURA MASTIGATÓRIA EM FUNÇÃO DO USO DE UM APARELHO REPOSICIONADOR MANDÍBULO-LINGUAL EM PACIENTES PORTADORES DE APNEIA OBSTRUTIVA DO SONO E RONCO}

\section{Fernando Gonçalves Junqueira Leite}

Orientadora: Profa. Dra. Fabiana Cardoso Pereira Valera

Dissertação de Mestrado apresentada em 12/03/2012

Objetivo: Verificar o efeito do uso do aparelho reposicionador mandíbulo-lingual (ARML) sobre o índice de apneia e hipoapnea (IAH) determinado pelo exame de polissonografia; as médias de atividades eletromiográficas dos músculos masseter e temporal (EMG) e a força de mordida molar máxima em pacientes portadores de síndrome da apneia obstrutiva do sono (SAOS) leve e moderada.

Materiais e métodos: Dezenove pacientes com diagnóstico de SAOS leve ou moderada encontrado ao exame de polissonografia (PSG) prévio e aumento da base de língua observado no exame de nasofibroscopia foram incluídos no estudo e submetidos à EMGe para obtenção da força de mordida molar máxima de ambos os lados, e em seguida iniciouse a moldagem para confecção do (ARML) que seria utilizado para o tratamento e com o qual estes pacientes deveriam 
dormir. A PSG foi repetida após três meses de uso do ARML para determinação do novo IAH, e a EMG após seis e doze meses de tratamento. Após os exames foram realizadas as análises estatísticas utilizando o teste de medidas repetidas ao longo do tempo (SPSS 17.0).

Resultados: Houve diminuição média significativa de IAH de 13,78 para 7,85 quando comparadas a PSG inicial e a com uso do ARML. A taxa de cura completa com o ARML ficou em 52,6\%, e a parcial em 68,4\%. Não houve correlação dos resultados com idade ou índice de massa corporal (IMC) dos pacientes. Não se verificou alteração estatística significativa comparando os resultados dos exames de EMG e força de mordida, inicial, de seis e doze meses.

Conclusão: O ARML, em pacientes com aumento de base de língua e SAOS leve e moderada, reduziu o IAH sem causar dano aos músculos masseter e temporal que pudesse ser evidenciado pela EMG.

\title{
Ortopedia, Traumatologia e Reabillitação
}

\section{ANÁLISE DO SINERGISMO MUSCULAR DURANTE A PREENSÃO PALMAR APÓS REPARO CIRÚRGICO DOS TENDÕES FLEXORES DA MÃO}

\author{
Aline Miranda Ferreira \\ Orientadora: Prof ${ }^{a} \operatorname{Dr}^{a}$ Marisa de Cássia Registro Fonseca \\ Dissertação de Mestrado apresentada em 11/01/2012
}

A diminuição da força de preensão palmar é frequentemente observada após reparo cirúrgico dos tendões flexores da mão. Para o melhor desempenho desta função é necessário que haja sinergismo adequado entre a musculatura flexora de dedos e extensora de punho, bem como um posicionamento articular ideal. Os objetivos deste estudo foram analisar a atividade eletromiográfica dos músculos extensor carpi radialis (ECR) e flexor digitorum superficialis (FDS), bem como correlacionar esta ativação com a amplitude de movimento (ADM) do punho durante a tarefa de preensão isométrica máxima entre indivíduos na fase intermediária de reabilitação após reparo dos tendões flexores e indivíduos saudáveis.

Métodos: Onze sujeitos, com 8,9 + 0,7 semanas de pós-operatório de lesão na zona V, participaram do grupo lesado. Onze sujeitos, sem lesão, participaram do grupo controle.

Resultados: $O$ grupo lesado apresentou valores inferiores ao controle na atividade eletromiográfica, com razão média de co-ativação entre FDS e ECR de 1: 0,87 + 0,17 no grupo controle, e de 1: 0,56 + 0,23 no grupo lesado ( $\mathrm{p} \leq 0,05)$. A média de ADM do punho durante a tarefa foi $1,37+8,74^{\circ}$ em flexão no grupo lesado, significantemente menor ao grupo

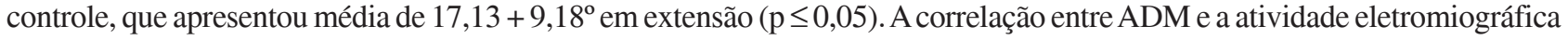
do ECR esteve presente somente no grupo lesado $(r=0,32)$.

Conclusão: A diminuição na atividade eletromiográfica dos músculos ECR e FDS, bem como da co-ativação entre eles, sugere um déficit no sinergismo muscular, diminuindo a estabilização do punho durante a preensão palmar nos indivíduos após reparo cirúrgico dos tendões flexores. Isto parece estar relacionado ao déficit da articulação punho em se manter em extensão durante a tarefa.

\section{RESISTÊNCIA MECÂNICA DA FIXAÇÃO COM PLACAS DE COMPRESSÃO DE 3,5 MM COM QUATRO, CINCO E SEIS ORIFÍCIOS}

\author{
Alex Eduardo Calderón Irusta \\ Orientador: Prof. Dr. Cláudio Henrique Barbieri \\ Dissertação de Mestrado apresentada em 18/01/2012
}

Objetivo: quantificar a resistência mecânica das fixações com placas de compressão dinâmica (DCP) de 3,5 mm de quatro, cinco e seis orifícios, submetidas a esforços de torção e flexão em dois pontos, com alteração da posição da montagem em relação ao vetor de carga nesta última.

Métodos: foram construídos modelos de madeira simulando fraturas transversas do antebraço, fixados com compressão axial de acordo com o método AO. Os modelos foram divididos em três grupos de acordo com o tamanho da placa e submetidos a esforços de flexão superior, lateral e inferior, conforme a posição do modelo na máquina e a direção da aplicação da carga, e a torção em uma máquina universal de ensaios. Cada modelo foi submetido aos quatro testes, sendo avaliadas deflexão, rigidez e resiliência. 
Resultados: a placa de seis orifícios apresentou valores menores de deflexão e resiliência e maior de rigidez do que a placa de quatro orifícios, tanto à flexão, como à torção $(\mathrm{p}<0,001)$. Igualmente, a deflexão e a resiliência foram menores e a rigidez foi maior para a posição superior da placa do que para a inferior $(\mathrm{p}<0,001)$. A posição lateral e a placa de cinco orifícios ficaram numa posição intermediária, com um comportamento variável irregular de acordo com o parâmetro avaliado.

Conclusão: as diferenças observadas nos parâmetros analisados para cada tamanho de placa foram pequenas, com a placa de seis orifícios apresentando o melhor desempenho, embora não proporcional ao incremento da área de fixação.

\title{
PROPOSTA DE UM PROTOCOLO DE TRATAMENTO FISIOTERAPÊUTICO BASEADO NO MÉTODO DE FACILITAÇÃO NEUROMUSCULAR PROPRIOCEPTIVA EM PORTADORES DE NEUROPATIA HEREDITÁRIA MOTORA E SENSITIVA DO TIPO CHARCOT-MARIE-TOOTH
}

\author{
Luciana Hata \\ Orientador: Prof. Dr. João Eduardo de Araújo \\ Dissertação de Mestrado apresentada em 24/01/2012
}

A doença de Charcot-Marie-Tooth (CMT) é a neuropatia hereditária motora e sensitiva (NHMS) mais prevalente, acometendo 1 pessoa a cada 2500. A CMT tipo 1A(CMT1A) é a mais comum, causando desmielinização das fibras nervosas, lenta e progressiva, reduzindo a velocidade de condução nervosa (VCN), produz fraqueza dos músculos distais, atrofia e deformidade dos pés e nas mãos, perda de sensibilidade e fadiga muscular. Participaram desse estudo 15 sujeitos portadores de CMT1A. Os sujeitos foram alocados em um único grupo e receberam um protocolo de tratamento fisioterapêutico por Facilitação Neuromuscular Proprioceptiva (FNP), que é composto por padrões de movimentos em diagonais e irradiação de força muscular, durante cinco semanas. Os sujeitos foram avaliados pelos testes funcionais (Timed Up and Go e o teste de $10 \mathrm{~m}$ ) e avaliação com Eletromiografia (EMG) de superfície para root mean square e Fadiga Muscular (RMS e FMed, respectivamente). Os eletrodos foram colocados no ponto motor do músculo tibial anterior (TA) e a análise durante a dorsiflexão ativa, no início, ao final e nos seguimentos de 30 e 90 dias após a finalização do protocolo. Para a análise dos dados, devido à distribuição anormal da amostra, foi utilizado o teste em t para amostras pareadas de Wilcoxon (comparação início e fim do protocolo). Para comparação dos valores do seguimento após 30 e 90 dias utilizado uma análise da variância de uma via ranqueada pelo teste de Kruskal-Wallis, diferenças entre grupos foi evidenciada pelo teste de Dunn's. Valores significativos p<0,05. Os resultados obtidos da EMG foram: RMS sujeitos em decúbito dorsal, TAD: $\mathrm{t}=-2,60$ e H=1,20*; TAE: $\mathrm{t}=-1,90$ e $\mathrm{H}=15,46^{*}$; RMS sentados, TAD: $\mathrm{t}=-2,20$ e $\mathrm{H}=3,33 *$; TAE: $\mathrm{t}=-0,87$ e $\mathrm{H}=2,01$. FMed, sujeitos em decúbito dorsal, TAD: $\mathrm{t}=-1,34$ e $\mathrm{H}=0,64$; TAE: $\mathrm{t}=-1,02$ e $\mathrm{H}=1,41$; FMed sentados, TAD: $\mathrm{t}=-0,31$ e $\mathrm{H}=6,66$; TAE: $\mathrm{t}=-0,29$ e $\mathrm{H}=2,43$. Testes de funcionalidade, TUG: $\mathrm{t}=4.83$ e $\mathrm{H}=15,93 *$ e T10m: $\mathrm{t}=4.30$ e $\mathrm{H}=12.27 *$. A melhora significativa dos valores de RMS do músculo TA e melhora nos testes funcionais de locomoção (TUG e T10m) sugerem eficácia do protocolo baseado na FNP por possíveis modificações corticais, uma vez que não existe melhora nos nervos periféricos na CMT1A. A ausência de uma melhora da resposta de FMed corrobora essa hipótese. Como os resultados não se mantém após a interrupção do protocolo sugerimos a manutenção contínua do tratamento fisioterapêutico para os pacientes portadores de CMT1A.

\section{Patologia}

\section{AVALIAÇÃO ANTROPOMÉTRICA DE CRÂNIOS ENCAMINHADOS AO CENTRO DE MEDICINA LEGAL DA FACULDADE DE MEDICINA DE RIBEIRÃO PRETO DA UNIVERSIDADE DE SÃO PAULO - USP, PARA FINS DE INVESTIGAÇÃO DE ANCESTRALIDADE}

\author{
Ana Paula de Souza Velloso \\ Orientador: Prof. Dr. Marco Aurélio Guimarães \\ Dissertação de Mestrado apresentada em 25/01/2012
}

A Antropologia Forense é uma especialidade relativamente recente, cujos métodos são da antropologia física e arqueologia, para a coleta e análise de evidências legais, buscando estabelecer a identidade do sujeito através da individualização de características intrínsecas àquela situação. Essa técnica se iniciou no século XX e vem sendo incrementada por causa do exponencial aumento da violência, exigindo o conhecimento da anatomia do esqueleto em ações jurídicas, que envolvem a identificação e avaliação de restos humanos em decomposição ou esqueletizados. No 
presente trabalho foi usado o termo Ancestralidade, por ser atualmente, usado mundialmente pelos profissionais da Antropologia Forense. A literatura mostra, através de Retzius (1845) e posteriormente outros autores, tais como: Elliott (2009); Collard (2009); Ward \& Jamison (1991); Vanrell (2008); Campos (2008); Sauer (1992); Pontikos (2004); Ousley, Jantz e Freid (2009), que Índices Cranianos podem ser utilizados para a finalidade de determinação de ancestralidade. Considerando a diversidade da miscigenação na população brasileira, assim como a ausência de dados descritivos sobre as características morfológicas de crânios de miscigenados e diante da revisão bibliográfica apresentada, este trabalho é centralizado na elaboração de uma descrição técnica precisa da localização dos pontos craniométricos e sobre como utilizá-los para obtenção, de forma pragmática, dos índices de Retzius (Horizontal, Sagital, Transversal, Facial Superior e Nasal) para fins de estimativa de ancestralidade em crânios brasileiros, incluindo a possibilidade de detecção de miscigenação ancestral, com o intuito de contribuir em perícias antropológico- -forenses de identificação humana. Foram analisados quarenta e dois crânios das ossadas disponíveis no Centro de Medicina Legal da Faculdade de Medicina de Ribeirão Preto da Universidade de São Paulo (CEMEL / FMRP-USP) e viáveis para a execução da pesquisa. Com base nos resultados dos índices craniométricos obtidos, observou-se que há a detecção de mais de uma ancestralidade para um mesmo crânio. Dessa maneira a realização do exame de estimativa ancestral de crânios através da craniometria pode não ser viável para um laboratório de antropologia forense brasileiro, apesar de ser uma técnica mensurável.

\title{
CÉLULAS PROGENITORAS HEPÁTICAS EXPRESSAM P63 NO FÍGADO HUMANO E DE RATOS
}

\author{
Luísiane de Ávila Santana \\ Orientador: Prof. Dr. Fernando Silva Ramalho \\ Tese de Doutorado apresentada em 01/03/2012
}

O futuro de terapias clínicas hepáticas dependerá da identificação de precursores celulares capazes de gerar novas células hepáticas funcionais. Em situações nas quais hepatócitos estão impedidos de se replicar, o fígado adulto passa a utilizar seu compartimento de células progenitoras. Sabe-se que o p63 possui importante papel na manutenção de células progenitoras de diversos tecidos epiteliais. O objetivo do presente estudo foi avaliar a expressão da proteína p63 e suas isoformas (TAp63 e $\Delta \mathrm{Np} 63$ ) em células progenitoras hepáticas humanas e de ratos. Animais submetidos a hepatectomia $70 \%$ e tratados com 2-acetilaminofluoreno foram sacrificados 4, 7,9 e 11 dias pós-hepatectomia. Grupo adicional de ratos foi submetido a hepatectomia 95\% e sacrificado 24 horas pós-cirurgia. Amostras hepáticas e de medula óssea de crianças recém-nascidas prematuras, e fragmentos hepáticos de pacientes adultos com quadro clínico de falência hepática aguda também foram utilizados no experimento. A pesquisa da proteína p63 foi realizada pelos métodos imunohistoquímico e de western blotting, enquanto a expressão gênica foi avaliada por RT-PCR. Células progenitoras hepáticas humanas e de ratos exibiram simultânea marcação para p63 e c-kit, com isolamento e identificação de p63 e suas isoformas por western blotting. A maior população de células ovais identificadas pelas proteínas p63 ou OV6 foi obtida 7 dias pós-hepatectomia, sendo verificada ainda expressão de p63 em hepatócitos imaturos. Adicionalmente, a expressão gênica das isoformas TAp63 e $\Delta$ Np63 foi identificada nos fígados dos animais. Não houve identificação de p63 nas amostras de medula óssea. O presente estudo possibilita a inclusão da proteína p63 como um novo marcador das células progenitoras hepáticas oriundas de células-tronco do próprio fígado.

\section{RELAÇÃO ENTRE O GENE B-CELL-SPECIFIC MOLONEY MURINE LEUKEMIA VIRUS INTEGRATION SITE 1 (BMI-1) E GENES REGULADORES DA RECOMBINAÇÃO HOMÓLOGA EM CARCINOMAS DUCTAIS INVASORES DA MAMA}

\author{
Giórgia Gobbi da Silveira \\ Orientador: Prof. Dr. Alfredo Ribeiro da Silva \\ Dissertação de Mestrado apresentada em 02/03/2012
}

Bmi-1 é uma proteína do grupo Polycomb capaz de induzir atividade de telomerase, levando à imortalização de células epiteliais. As células, quando imortalizadas, se tronam mais susceptíveis a danos em dupla fita (double-strand breaks (DSB))e a recombinação homóloga é uma das duas vias de reparo dos DSBs. Dentre os genes reguladores da recombinação homóloga temos o BRCA-1, que está envolvido na resposta ao dano associado à proteína RAD51, que por sua vez se acumula rapidamente nos focos de dano ao DNA após a sinalização do H2AX, que têm se mostrado um excelente marcador de dano celular por se acumular rapidamente nos focos de lesão, desencadeando o processo de reparo. Topoisomerase III $\beta$ (TopoIII $\beta$ ) remove intermediários da recombinação homóloga antes da segregação de cromossomos, prevenindo danos à 
estrutura do DNA celular. O papel das proteínas envolvidas na recombinação homóloga, em carcinomas ductais invasores positivos para o BMI-1, necessita ser investigado. Utilizando-se tissue microarrays contendo 239 casos de carcinomas ductais mamários primários, foi analisada a expressão imunoistoquímica de BMI-1, receptor de estrógeno, receptor de progesterona, HER-2, Ki67, p53 e BRCA-1, $\gamma \mathrm{H} 2 \mathrm{AX}$, RAD51 e topoisomerase III $\beta$. Positividade para o Bmi- 1 foi encontrada em 66 casos (27.6\%). A positividade imunoistoquímica do BMI-1 relacionou-se a $R E(p=0,004), R P(p<0,001), K i-67$ (p < 0,001), p53 ( $\mathrm{p}=0,003)$, BRCA-1 $(\mathrm{p}=0,003), \mathrm{H} 2 \mathrm{AX}(\mathrm{p}=0,024)$ e TopoIII $\beta(\mathrm{p}<0,001)$. Concluindo, nossos resultados mostraram haver relação entre o BMI-1 e genes reguladores da HR, sugerindo que a positividade de BMI-1 pode ser um importante evento na recombinação homóloga em carcinomas ductais invasores da mama.

\title{
Saúde da Criança e do Adolescente
}

\section{TOXOPLASMOSE CONGÊNITA EM SERGIPE: PREVALÊNCIA AO NASCER E EVOLUÇÃO CLÍNICA}

\author{
Ana Dorcas de Melo Inagaki \\ Orientadora: Prof ${ }^{a}$ Dr $^{a}$ Marisa Márcia Mussi Pinhata \\ Tese de Doutorado apresentada em 19/01/2012
}

Introdução: Estimativas da ocorrência de toxoplasmose congênita (TC) em recémnascidos brasileiros têm sido feitas por meio do rastreamento neonatal. Todavia, concentram-se em populações da região sul e sudeste do país. Objetivos: Considerando-se a relevância para o planejamento de políticas em saúde, este estudo visou estimar a prevalência ao nascer de TC entre nascidos vivos no estado de Sergipe e pretendeu conhecer a frequência de acometimento visual e neurológico nas crianças infectadas.

Método: O estudo ocorreu em duas etapas. Na primeira, foi verificada a presença de IgM contra Toxoplasma gondii por meio da analise de amostras de sangue absorvido em papel filtro de 15.204 crianças nascidas vivas. As amostras foram analisadas utilizando-se o ensaio laboratorial do tipo ELISA por captura [Q-Preven Toxo IgM - DBS]. Nesta etapa, 233 amostras revelaram-se reagentes e/ou duvidosas para a presença de IgM sendo repetidas em duplicata, utilizando-se a mesma amostra e o mesmo ensaio laboratorial. Após a repetição em duplicata, 53 permaneceram reagentes e/ou duvidosas, sendo esses pares, mãe-criança, convocados para a segunda fase do estudo. Nessa fase, os pares foram submetidos à coleta de sangue periférico para confirmação diagnóstica por meio de detecção quantitativa de IgG e qualitativa de IgM contra o toxoplasma, ambos utilizando o ensaio laboratorial "Microparticle Enzime Immunoassay" (MEIA). Para conhecermos o estado sorológico das mães durante o prénatal consultamos o banco de dados da testagem pré-natal. As crianças foram submetidas a exame clínico completo, avaliação oftalmológica, ultrassonografia transfontanelar e exame de líquor cefalorraquídeo para verificação da extensão do acometimento e da necessidade de tratamento. Crianças que apresentaram sinais compatíveis com a infecção congênita foram submetidas à avaliação da função hepática (TGO, TGP, BT, BD, ãGT), além de excluídas outras infecções perinatais, tais como sífilis (através de exame de VDRL), rubéola (utilizando metodologia MEIA) e Citomegalovírus -CMV (utilizando amostra de saliva e do sangue para detecção do DNA viral por PCR). Durante o seguimento, foram repetidos testes de IgG e IgM anti- T.gondii trimestralmente das crianças com provável TC, além do seguimento clínico, oftalmológico e da avaliação do crescimento e desenvolvimento.

Resultados: Seis crianças eram confirmadamente acometidas pela TC e nenhuma tinha sido diagnosticada durante o pré-natal. A prevalência estimada de TC foi de 4/10.000 [IC 95\%: 1,4 - 8,0/:10.000]. À avaliação inicial, somente uma $(16,7 \%)$ criança possuía achado clínico no exame rotineiro, quando se acrescentaram recursos para avaliação complementar, mais duas crianças apresentaram alterações decorrentes da toxoplasmose congênita. Assim, três (50,0\%) crianças apresentaram achados relacionados à infecção pelo Toxoplasma gondii, uma com hepatoesplenomegalia, outra com coriorretinite e a terceira com calcificação cerebral. No decorrer do primeiro ano de vida mais duas crianças apresentaram coriorretinite, sendo uma anteriormente assintomática e a segunda criança já apresentava hepatoesplenomegalia, essa ultima desenvolveu coriorretinite em ambos os olhos, totalizando três crianças $(50,0 \%)$ com alterações oculares decorrentes da TC. Nenhuma dessas apresentou alterações neurológicas. As demais duas crianças permaneceram assintomáticas após os 20 meses de seguimento.

Conclusão: A TC é um problema relevante no Estado de Sergipe com prevalência ao nascer de 4/10.000 nascidos vivos e alta morbidade. 


\title{
VALIDAÇÃO RELATIVA DE QUESTIONÁRIO QUANTITATIVO DE FREQUÊNCIA ALIMENTAR PARA CRIANÇAS DE 5 A 10 ANOS
}

\author{
Lidiane Bernardes Faria Vilela
}

Orientadora: Profa. Dra. Jacqueline Pontes Monteiro

Tese de Doutorado apresentada em 10/02/2012

Avaliar a ingestão alimentar é um desafio muito grande para pesquisadores e, em se tratando de crianças, esse desafio é ainda maior. Nesta situaço o que se pretende, mais do que estimar corretamente o padrão usual de consumo é classificar corretamente os indivíduos, segundo maior ou menor consumo. Porém, é necessário determinar a validade de questionários alimentares.

Objetivo: Testar a validade de um Questionário Quantitativo de Frequência Alimentar (QQFA) para crianças de 5 a 10 anos de idade do Município de Rio Verde do Estado de Goiás, que inclua alimentos usuais da populaço, por meio de comparaço com Inquérito Recordatório de 24horas (IR24h), no que diz respeito a energia, macronutrientes, fibras, vitaminas $\mathrm{C}$, A e folato.

Metodologia: Após a aplicaço do QQFA, foram aplicados três IR24h, desta forma foram registrados todos os alimentos e bebidas, e suas respectivas medidas caseiras, consumidos para avaliaço da ingestão usual de energia e nutrientes. Foram calculadas as medianas, valores mínimos e máximos e coeficiente de correlaço de Pearson utilizando-se o programa SPSS. O programa MedCalc Statistic versão 11.6.0 foi utilizado para estatística de Kappa e Bland-Altman.

Resultados: A amostra foi composta por 114 crianças, dessas 52,6\% eram do sexo feminino e 47,4\% eram do sexo masculino. A mediana de idade foi de 7 anos. A maioria era eutrófico $(69,3 \%)$, com IMC mediano de $15,37 \mathrm{~kg} / \mathrm{m} 2$. Os resultados dos coeficientes de correlaço de Pearson apresentaram valores baixos para todos os nutrientes, exceto para proteína e vitamina $\mathrm{C}(\mathrm{r}=0,39 \mathrm{e} \mathrm{r}=0,33$, respectivamente). Após o ajuste pela energia, a correlaço dos nutrientes diminuiu tendendo em alguns casos a valores negativos, como foi caso do carboidrato e da fibra. Quando atenuaram-se os efeitos da variância intrapessoal, valores baixos foram mantidos; exceto para energia, que apresentou um aumento $(r=0,306)$ e o da vitamina $\mathrm{C}$ que ficou em $\mathrm{r}=0,3$. Na estatística de Kappa para análise de concordância entre quartis, foi encontrada uma boa concordância para os nutrientes energia, proteína e folato (71\%), seguido das vitaminas C (69\%) e A (67\%). Quando avaliados os quartis opostos observou-se uma média de 9,95\% para os nutrientes analisados. A estatística Kappa revelou uma relativa a nenhuma concordância entre os métodos sendo a maior concordância para o nutriente Energia $(0,27)$ e a menor para o Carboidrato (- 0,09). A análise Bland-Altman mostrou concordância entre os métodos QQFA e IR24h de 95\% para fibra a 332\% para vitamina A. O gráfico de dispersão de Bland-Altman mostrou valores de $p<0,001$ para os nutrientes vitamina C, vitamina A e Folato que indicam erros sistemáticos do tipo, subestimativa de maiores ingestões para as vitaminas $\mathrm{C}$ e $\mathrm{A}$ e superestimativa de menores ingestões para folato.

Conclusão: Pela análise de Bland-Altman o QQFA superestima todos os nutrientes avaliados pelo IR24, porém se apresenta como um bom instrumento para análise da ingestão de energia, carboidrato, proteína, lipídio, fibra, vitamina A, vitamina $\mathrm{C}$ e folato, quando divididos em quarto de consumo pela estatística de Kappa, para crianças de 5 a 10 anos do município de Rio Verde do estado de Goiás.

\section{EFEITO DA EDUCAÇÃO ALIMENTAR BASEADA NA ADEQUAÇÃO DO PORCIONAMENTO DOS ALIMENTOS, NA ALTERAÇÃO DA COMPOSIÇÃO CORPORAL DE ADOLESCENTES OBESOS ATENDIDOS EM UM SERVIÇO AMBULATORIAL}

\author{
Cristina Maria Mendes Resende \\ Orientadora: Profa. Dra. Jacqueline Pontes Monteiro \\ Tese de Doutorado apresentada em 27/02/2012
}

Objetivo: Comparar o efeito da educação nutricional qualitativa com a educação nutricional qualitativa associada a orientações quanto ao porcionamento alimentar (quantitativa), na redução de massa corporal gorda (MG) em adolescentes obesos; comparar valores antropométricos, de composição corporal, e o tamanho usual de porções alimentares de adolescentes obesos, antes e após as intervenções nutricionais; comparar a composição corporal determinada pela Impedância Bioelétrica (BIA) e pelo Método da Diluição do Óxido de Deutério (MDOD), identificar correlações e concordâncias entre os métodos e elaborar modelos de regressão linear visando a prever os valores do MDOD, utilizando os dados da BIA. 
Metodologia: Trata-se de um ensaio clínico randomizado, onde adolescentes de ambos os sexos com obesidade, atendidos em um ambulatório de obesidade infantil, foram alocados aleatoriamente em dois grupos. O grupo A (GA adequando o tamanho da porção) foi submetido à avaliação antropométrica (peso, altura e circunferência da cintura), à análise da composição corporal avaliada pela BIA e pelo MDOD, à intervenção nutricional qualitativa e adequação do tamanho da porção alimentar. O grupo B (GB) foi submetido às mesmas avaliações antropométricas e de composição corporal e recebeu a mesma abordagem nutricional exceto as orientações para ajustar o tamanho da porção alimentar. A orientação quanto ao porcionamento alimentar no GB foi fornecido no nono, ou seja, último encontro. Para a elaboração da equação de regressão linear, foram considerados somente os dados da BIA e do MDOD de todos os pacientes antes da intervenção (estudo tipo corte transversal, observacional e descritivo).

Resultados: No GA (27 adolescentes) ocorreu diminuição significativa do índice da massa corporal (IMC), da MG avaliada pelo MDOD (MGD, \%), e pela BIA (MGB, \%) e no GB (n=26), da MGD (\%). Constatou-se que, antes da intervenção, os adolescentes de ambos os sexos e grupos apresentaram consumo excessivo dos grupos alimentares: carboidratos complexos, leguminosas, carnes, carboidratos simples e gorduras e baixo consumo do grupo das hortaliças. Em ambos os sexos e grupos, houve diminuição significativa dos grupos: carboidratos complexos, carboidratos simples e gorduras, aproximando das recomendações. As adolescentes do sexo feminino do GA apresentaram diminuições positivas para o grupo das carnes e de forma negativa para o grupo das frutas. No GB, os adolescentes do sexo masculino apresentaram diminuição negativa para os grupos de frutas e leite. O consumo de hortaliças foi abaixo da recomendação em ambos os grupos e sexos, antes e após a intervenção. O trabalho de intervenção no GA apresentou valores de MGD (kg) significativamente menores do que no GB. A BIA superestimou os valores de massa livre de gordura (MLG, kg e \%) e de água corporal total (ACT, Le \%) e subestimou os valores de MG ( kg e \%). Foi observada uma não concordância entre os valores de MLG $(\mathrm{kg}), \mathrm{MG}(\mathrm{kg})$ e ACT (L) obtidos pela BIA e MDOD. Os valores preditos pelo modelo aproximamse dos valores reais observados pelo MDOD, utilizando ajustes dos modelos de regressão 0,8636 × MLG avaliada pela BIA (MLGB); 1,192 $\times$ MGB; 0,8332 × ACT avaliada pela BIA (ACTB).

Conclusão: $O$ trabalho de intervenção no GA foi mais eficiente, pois apresentou valores de MGD (kg) significativamente menores. Observou-se diminuição de MGD (\%) em ambos os grupos, assim como do consumo diário de forma positiva de carboidratos complexos, carboidratos simples e gorduras em ambos os grupos de intervenção e sexo. As adolescentes (GA) diminuíram positivamente o consumo do grupo das carnes e negativamente das frutas, enquanto os adolescentes (GB - sexo masculino) diminuíram negativamente os grupos de frutas e leites. Os valores da composição corporal determinados pela BIA e pelo MDOD foram significativamente diferentes, tendo sido encontrada correlação positiva significativa, porém não concordância. Foi possível predizer valores de composição corporal determinados pelo MDOD em adolescentes obesos, usando os valores obtidos pela BIA por meio de ajustes de modelos de regressão linear.

\title{
Saúde Mental
}

\section{EFEITO DO SUMATRIPTANO NO TESTE DA SIMULAÇÃO DE FALAR EM PÚBLICO}

\author{
Marcos Gonçalves de Rezende; \\ Orientadora: Profa. Dra. Cristina Marta Del-Ben \\ Dissertação de Mestrado apresentada em 31/01/2012
}

O Teste da Simulação de Falar em Público (SFP) é um teste sensível a drogas que interferem com a neurotransmissão mediada por serotonina (5-HT), e algumas evidências sugerem que ele possa recrutar os mesmos sistemas neuronais envolvidos na fisiopatogenia do Transtorno do Pânico (TP). Diferentes fármacos que, direta ou indiretamente, modulam receptores serotoninérgicos, já foram testados em voluntários saudáveissubmetidos ao SFP, mas nenhum estudo, até o momento, utilizou drogas que permitissem avaliar o papel de receptores do tipo 5-HT1D na ansiedade. O sumatriptano, um agonista específico de receptores 5-HT1D, parece ser um bom candidato como sonda farmacológica, tendo em vista sua ampla utilização na prática clínica para o tratamento de enxaqueca, com segurança e boa tolerabilidade. A hipótese testada neste estudo foi a de que, devido à ativação de receptores pré-sinápticos 5-HT1D e consequiente redução na liberação de 5-HT, o sumatriptano aumentaria o medo provocado pelo SFP. Para tanto, foi conduzido um estudo duplo cego, randomizado, utilizando 36 voluntários saudáveis do sexo masculino, distribuídos em três grupos de tratamento: placebo (n = 12), $50 \mathrm{mg}(\mathrm{n}=12)$ ou 100mg $(\mathrm{n}=12)$ de sumatriptano, administrado duas horas antes do SFP. Antes, durante, e após o SFP, medidas subjetivas de ansiedade foram registradas através da Escala Analógica Visual do Humor (VAMS) e da Escala dos 
Sintomas Somáticos (ESS). Também foram tomadas medidas fisiológicas de ansiedade (pressão arterial, frequiência cardíaca, dosagem hormonal e eletrocondutância da pele). Os resultados foram submetidos à análise multivariada de variância, covariando com a medida basal (MANCOVA). O grupo tratado com $100 \mathrm{mg}$ de sumatriptano apresentou aumento mais pronunciado da ansiedade subjetiva do que os grupos tratados com $50 \mathrm{mg}$ e com placebo durante as fases de preparação e de desempenho. O grupo tratado com $100 \mathrm{mg}$ de sumatriptano também mostrou-se mais alerta na fase de preparação e desempenho do que o grupo placebo. Houve queda dose-dependente da prolactina. Já o cortisol plasmático, quando analisado de forma global sem distinguir grupos, teve um aumento após o teste. Inferimos, portanto, que o efeito ansiogênico gerado pelo teste esteja relacionado com a diminuição da 5-HT na matéria cinzenta periaquedutal (MCP). Corroborando a Teoria do Papel Dual da Serotonina, segundo a qual a diminuição de 5-HT na matéria cinzenta periaquedutal dorsal (MCPD) aumentaria o medo incondicionado. Devido a esse efeito ansiogênico do uso agudo do sumatriptano também ocorrer na prática clínica em pacientes com migrânea, deve-se atentar para a possibilidade da manifestação de sintomas semelhantes aos de ataque de pânico em pacientes ansiosos. Por sua vez, a diminuição da prolactina foi ocasionada pelo efeito do sumatriptano na facilitação da liberação de dopamina e conseqüente queda da prolactina. Já o aumento do cortisol plasmático reflete a ativação do eixo hipotálamo-hipófise-adrenal (HHA) provocada pelo SFP. A interpretação da resposta do cortisol ao estresse psicológico é complexa e depende de vários fatores, como tema do discurso, tipo de avaliação social, falta de controle da situação, tamanho amostral, estratégias de regulação emocional do voluntário. Mais estudos são necessários para elucidar o papel dos receptores 5-HT1D na ansiedade e para compreender a resposta do cortisol ao estresse psicológico.

\title{
ESTUDO DOS EFEITOS DA OCITOCINA EM MODELOS DE ANSIEDADE GENERALIZADA E DE PÂNICO EM RATOS E EM VOLUNTÁRIOS SAUDÁVEIS
}

\author{
Danielle Chaves Gomes de Oliveira \\ Orientador: Prof. Dr. Antonio Waldo Zuardi \\ Tese de Doutorado apresentada em 29/02/2012
}

A ocitocina (OT) é um nonapeptídeo sintetizado nos núcleos paraventricular e supraóptico do hipotálamo, com ação periférica e no Sistema Nervoso Central. Atua como neuromodulador em diversos processos, incluindo uma possível ação ansiolítica, embora não esteja claro se este efeito é específico para alguma condição ou transtorno de ansiedade. Desta forma, objetivamos avaliar a ação da OT em: a- modelos de ansiedade generalizada e pânico em ratos; b. modelo de ansiedade generalizada em voluntários saudáveis. Nos estudos com ratos, utilizamos o modelo do labirinto em T elevado como modelo de ansiedade generalizada e pânico, e a estimulação elétrica da substância cinzenta periaquedutal dorsal (SCPd) como modelo de pânico. No estudo com voluntários saudáveis utilizamos a inalação de 7,5\% de CO2 durante 20 minutos como modelo de ansiedade generalizada. Os resultados em animais indicaram que a OT, quando administrada agudamente no ventrículo lateral, possui efeito do tipo ansiogênico sobre as latências de esquiva inibitória no labirinto em T elevado. No entanto, quando administrada na SCPd possui efeito ansiogênico sobre as latências de esquiva e efeito panicolítico sobre a latência de fuga. De maneira similar, quando a OT é administrada na SCPd possui um efeito inibitório tônico sobre a aversão gerada pela estimulação elétrica desta região, o que também sugere um efeito do tipo panicolítico. Em humanos, nossos dados demonstraram que, possivelmente, a OT tenha alguma função na modulação da ansiedade generalizada, uma vez que a sua administração preveniu o aumento da ansiedade induzida pela inalação de 7,5\% de $\mathrm{CO} 2$. Os resultados alcançados mostraram que o estudo da ação da OT em modelos do transtorno de ansiedade generalizada e do transtorno do pânico dependeu da rota de administração e do modelo em questão. Em conjunto, os resultados desse estudo são inconclusivos em relação aos efeitos da OT em modelos de ansiedade generalizada, porém sugerem um efeito da OT do tipo panicolítico em modelos de pânico em animais.

\section{ESTRESSE PRECOCE E ALTERAÇÕES DO EIXO HIPOTÁLAMO-PITUITÁRIA-ADRENAL (HPA) NA DEPRESSÃO}

\section{Cristiane Von Werne Baes}

Orientador: Prof. Dr. Mário Francisco P. Juruena

Dissertação de Mestrado apresentada em 30/03/12

Introdução: Diversos estudos sugerem que o estresse nas fases iniciais de desenvolvimento pode induzir alterações persistentes na capacidade do eixo Hipotálamo-Pituitária-Adrenal (HPA) em responder ao estresse na vida adulta. O 
desequilíbrio do cortisol tem sido identificado como um correlato biológico dos transtornos depressivos. Essas anormalidades parecem estar relacionadas às mudanças na capacidade dos glicocorticóides circulantes em exercer seu feedback negativo na secreção dos hormônios do eixo HPA por meio da ligação aos receptores de mineralocorticóides (RM) e glicocorticóides (RG) nos tecidos do eixo HPA. Devido à grande variedade de estressores, assim como os diferentes subtipos de depressão, os achados dos estudos atuais têm sido inconsistentes. Dessa forma, necessitando de mais estudos para que se possa elucidar os mecanismos envolvidos na associação entre o estresse precoce e o desenvolvimento de quadros depressivos.

Objetivo: O objetivo deste estudo é avaliar a correlação entre Estresse Precoce e alterações no eixo HipotálamoPituitária-Adrenal e na função dos receptores glicocorticóides e mineralocorticóides em pacientes depressivos.

Metodologia: Foram recrutados inicialmente 30 sujeitos divididos em dois grupos: grupo de pacientes com diagnóstico de episódio depressivo atual $(n=20)$ e grupo de controles $(n=10)$. Posteriormente os pacientes foram divididos em outros dois grupos de acordo com o Estresse Precoce, compondo a amostra final por três grupos: grupo de pacientes depressivos com presença de Estresse Precoce $(n=13)$, grupo de pacientes Depressivos com Ausência de Estresse Precoce $(n=7)$ e grupo de controles $(n=10)$. Os pacientes foram avaliados por meio de entrevista clínica de acordo com os critérios diagnósticos do DSM-IV, para a confirmação do diagnóstico. Para avaliação da gravidade dos sintomas depressivos foi aplicada a Escala de Depressão de Hamilton (HAM-D21), sendo incluídos apenas pacientes com HAM-D21 $\geq$ 17.A presença de estresse precoce foi confirmada através da aplicação do Questionário Sobre Traumas na Infância (QUESI).Foram utilizados também a Escala de Avaliação de Depressão de Montgomery-Asberg (MADRS), o Inventário de Depressão de Beck (BDI), o Inventário de Ansiedade de Beck (BAI), a Escala de Ideação Suicida de Beck (BSI), a Escala de Desesperança de Beck (BHS), a Escala Hospitalar de Ansiedade e Depressão (HADS) e a Escala de Impulsividade de Barratt (BIS-11) para a avaliação de sintomas psiquiátricos. A avaliação endócrina foi controlada por placebo, cego por parte dos controles e pacientes, não randomizado, com desenho de medidas repetidas, onde os efeitos da Fludrocortisona $(0.5 \mathrm{mg})$ e da Dexametasona $(0.5 \mathrm{mg})$ foram avaliados através do cortisol salivare plasmático. A secreção de cortisol plasmático e salivar foi avaliada nos sujeitos, após a administração de uma cápsula de Placebo, Fludrocortisona e Dexametasona às $22 \mathrm{hs}$ do dia anterior. O cortisol salivar foi coletado às $22 \mathrm{~h}$, ao acordar, 30 e 60 minutos após acordar e antes da coleta plasmática, nos dias seguintes após os desafios.

Resultados: $\mathrm{Na}$ amostra de pacientes depressivos e controles, encontramos níveis significativamente menores de cortisol salivar ao acordar após a administração de Placebo entre os pacientes depressivos do que os controles. Encontramos também uma tendência dos pacientes apresentarem níveis maiores de cortisol salivar ao acordar do que os controles após a administração de Dexametasona. Quando avaliado o cortisol após a administração de Fludrocortisona, os pacientes apresentaram níveis significativamente menores de cortisol salivar 30 minutos após acordar e na Área Sob a Curva (AUC) do que os controles. Além disso, encontramos também uma tendência dos pacientes depressivos apresentarem níveis menores de cortisol salivar 60 minutos após acordar do que os controles. Quando comparados entre pacientes depressivos com presença e ausência de Estresse Precoce e controles, encontramos uma tendência de os pacientes depressivos com ausência de Estresse Precoce apresentarem níveis menores de cortisol salivar ao acordar do que os controles. As médias dos níveis de cortisol salivar ao acordar não diferiram entre os pacientes com presença de Estresse Precoce e os controles e entre os pacientes do grupo presença e do grupo ausência de Estresse Precoce. Com relação aos níveis de cortisol salivar após a administração de Dexametasona entre pacientes depressivos com presença e ausência de Estresse Precoce e controles, os pacientes depressivos com ausência de Estresse Precoce apresentaram níveis significativamente maiores de cortisol salivar ao acordar do que os controles. Encontramos também uma tendência dos pacientes com ausência de Estresse Precoce apresentarem níveis maiores de cortisol salivar ao acordar do que os pacientes com presença de Estresse Precoce, porém não foram encontradas diferenças significativas entre os pacientes com presença de Estresse Precoce e os controles.

Conclusão: Nossos dados demonstram uma hipoatividade do eixo HPA nos pacientes depressivos. Além disso, estes achados sugerem que esta desregulação do eixo HPA se deva em parte a uma diminuição da sensibilidade dos RG e uma hiperativação dos RM nos pacientes depressivos. No entanto, quando comparados pacientes depressivos com presença e ausência de Estresse Precoce, os desafios com agonistas seletivos como a Dexametasona (agonista RG) e a Fludrocortisona (agonista RM) não foram capazes de detectar esta diferença fisiopatológica e distinguir entre os diferentes tipos de psicopatologia. Dessa forma, estes resultados sugerem que estudos com um agonista misto (RG/RM) como a Prednisolona teriam potencial para distinguir os pacientes depressivos com presença de estresse precoce. 


\title{
EFEITO DA ADMINISTRAÇÃO DE OCITOCINA INTRANASAL A PACIENTES COM ESQUIZOFRENIA E VOLUNTÁRIOS SADIOS EM TESTE DE PAREAMENTO DE EMOÇÕES FACIAIS
}

\author{
Lígia Ribeiro Horta de Macedo; \\ Orientador: Prof. Dr. Antonio Waldo Zuardi \\ Dissertação de Mestrado apresentada em 30/03/2012
}

Introdução: A ocitocina é um peptídeo sintetizado nos núcleos paraventricular (NPV) e supraótico (NSO) do hipotálamo, que possui tanto ações periféricas, no trabalho de parto e amamentação, quanto ações centrais. Entre as ações centrais da ocitocina destacam-se aquelas relacionadas a comportamento social em mamíferos. Pesquisas em humanos sadios mostram que a administração de ocitocina aumentou o desempenho em tarefas de reconhecimento de emoção facial, como medo, raiva alegria e tristeza. A capacidade de reconhecer tais expressões é essencial para as relações sociais e está prejudicada na esquizofrenia.

Objetivo: Avaliar efeito de dose única de ocitocina intranasal em teste de pareamento de emoções faciais em portadores de esquizofrenia e em voluntários sadios.

Métodos: Foram avaliados 20 pacientes com esquizofrenia e 20 voluntários saudáveis, de modo duplo cego, cruzado, controlado com placebo, que receberam ocitocina e placebo em duas sessões, com intervalo entre elas de 15 dias. Foi usada uma tarefa computadoriza de pareamento de emoções faciais, que tinha como controle pareamento de identidades faciais, de figuras geométricas e de cores.

Resultados: Não foram encontradas diferenças no teste de pareamento de emoções faciais entre os sujeitos que receberam ocitocina e os que receberam placebo. Como já descrito, os pacientes com esquizofrenia apresentaram desempenho pior no teste de pareamento quando comprado aos voluntários saudáveis.

Conclusões: Embora tenha sido descrito que a ocitocina possa melhorar reconhecimento de emoções faciais, não foi encontrado esse tipo de efeito no presente estudo. Uma das possíveis justificativas para isso seria o tipo de teste utilizado, que não requeria nomeação de emoções, enquanto nos estudos que encontraram melhora do reconhecimento de emoções com uso de ocitocina, sempre existia esse tipo de tarefa.

\section{Saúde na Comunidade}

\section{CARACTERIZAÇÃO DA VIOLÊNCIA SEXUAL EM MULHERES NA CIDADE DE RIBEIRÃO PRETO - SP}

\author{
Cesário da Silva Souza \\ Orientador(a): Prof $^{\mathrm{a}}$.Dr ${ }^{\mathrm{a}}$. Elisabeth Meloni Vieira \\ Dissertação de Mestrado apresentada em 08/03/2012
}

A violência contra a mulher é fenômeno universal que atinge todas as classes sociais, etnias, religiões e culturas, ocorrendo em populações de diferentes níveis de desenvolvimento econômico e social. As mulheres que sofrem violência física perpetrada por parceiros íntimos também estão sob risco da violência sexual, indicando uma relação entre a violência física e psicológica. No Brasil, o tema ainda é pouco estudado; existem poucos dados confiáveis da violência sexual no país. A notificação, ponto de partida para a investigação, é muito inferior ao número de agressões que acorrem pelo fato de que muitas vítimas evitam a exposição pública. Mediante esse cenário, o estudo teve como objetivo principal caracterizar o perfil epidemiológico dos casos de violência sexual contra mulheres com idade igual ou superior a 14 anos, registrados na Secretaria Municipal de Saúde de Ribeirão Preto - SP. Trata-se de um estudo de caráter descritivo tipo levantamento, no período de 2006 a 2008. Foram consideradas 245 notificações as quais indicaram que $71,84 \%$ dos casos registrados eram de mulheres abaixo dos 30 anos, brancas $(62,4 \%)$, solteiras $(68,6 \%)$, com um nível educacional baixo $(59,2 \%)$ e sem nenhuma deficiência descrita $(84,9 \%)$. O agressor, na maioria dos casos, foi classificado como desconhecido (43,3\%), o estupro foi o agravo mais acometido (69\%), sendo a residência $(33,5 \%)$ o local mais frequente em que aconteceu a violência. Sabe-se que à violência sexual, na maioria das vezes, está associada a alguma outra. O presente estudo descreve que $67,8 \%$ dos casos registrados apresentavam a violência física associada, com valores similares à violência psicológica que representou $62 \%$ dos casos. Em 68\% dos casos notificados foram encaminhados para Ambulatório. Como conclusão, o estudo teve como propósito contribuir como mais um instrumento no combate a violência sexual, mediante sua relevância para a Saúde Pública. 


\title{
CARACTERIZAÇÃO DE CASOS DE VIOLÊNCIA CONTRA CRIANÇAS NOTIFICADOS NO MUNICÍPIO DE RIBEIRÃO PRETO-SP
}

\author{
Marilurdes Silva Farias \\ Orientadora: Profa. Dra. Elisabeth Meloni Vieira \\ Dissertação de Mestrado apresentada em 16/03/2012
}

No Brasil, os estudos sobre violência contra crianças, sobretudo a doméstica, ainda são insuficientes para o real dimensionamento do fenômeno. Neste país, como em outros, o problema tem provocado forte impacto na morbidade e mortalidade desta população e se constitui em um fenômeno de grande relevância para a saúde pública, em virtude de suas consequências. Essas não são apenas restritas à saúde física, mental e sexual da criança, mas também incluem problemas de dinâmica familiar, atingindo a sociedade como um todo. Esta dissertação busca caracterizar e dimensionar os casos de violência contra crianças, do nascimento aos nove anos, notificados no município de Ribeirão Preto-SP, no período de janeiro de 2006 a dezembro de 2008. Trata-se de um estudo descritivo do tipo levantamento, que utiliza dados dos registros de violência contra a criança, oriundos dos vários serviços (saúde, educação, jurídico, etc.) do município, e inseridos, no banco de dados da Secretaria Municipal de Saúde (Sistema VIVA). Foram realizadas análises descritivas, por meio dos cálculos das frequências absolutas e simples, bem como medidas de tendência central e de variabilidade. Totalizaram 498 notificações no período citado e o tipo mais notificado foi a violência física (59,2\%), seguida pela psicológica (38,6\%). A violência sexual e a negligência alcançaram percentuais de 36,7\% e 19,7\%, respectivamente. De um modo geral, o sexo feminino foi o que apresentou o maior percentual de notificações $(56,4 \%)$, a faixa etária mais atingida foi entre dois e três anos de idade (26,5\%). De acordo com as notificações, em 38,0\% dos casos, as crianças não apresentaram lesões físicas visíveis, a região do corpo mais atingida foi a cabeça/face (11,6\%), o meio de agressão mais utilizado foi a força corporal $(25,1 \%)$. O local de ocorrência preferido para prática de violência contra a criança foi a residência (75,5\%). A maioria dos agressores era do sexo masculino (64,8\%). Entre as categorias de agressores, outros agressores e o pai alcançaram, respectivamente, $39,1 \%$ e $22,8 \%$ dos casos. Em $42,9 \%$ dos casos, a evolução foi ambulatorial e em $43,4 \%$ dos casos notificados foram encaminhados para os Conselhos Tutelares. A pesquisa mostra que há, entre os casos notificados, maior proporção de violência nos menores de seis anos de idade, as várias formas de violência, exceto a sexual, prevaleceram no sexo masculino, o tipo de violência mais frequente foi a física, as lesões corporais ocorreram em $55,5 \%$ dos casos, a maioria concentrando-se em outras partes do corpo, como: região digestiva, olho, ouvido, vagina, ânus e nádegas $(33,1 \%)$. Há maior proporção de agressores masculinos, a residência foi o local preferido para a prática da violência contra a criança e a maior proporção de encaminhamentos foi para os Conselhos Tutelares.

\section{IDENTIFICAÇÃO DE PAPÉIS OCUPACIONAIS E SINTOMAS DEPRESSIVOS EM IDOSOS}

\author{
Claudia Aline Valente Santos \\ Orientador: Prof. Dr. Jair Lício Ferreira Santos \\ Dissertação de Mestrado apresentada em 23/03/2012
}

Acompanhando o processo de envelhecimento populacional no país, a freqüência de doenças crônicas tem aumentado, sendo comum a presença de comorbidades clínicas e a presença de sintomas depressivos. A tristeza e o afastamento de atividades cotidianas na velhice parecem ser aceitos socialmente, reforçando o preconceito contra as pessoas idosas. Objetivos: identificar a presença de sintomas depressivos e os papéis ocupacionais de idosos acompanhados em um Ambulatório de Triagem e Retornos Curtos de um hospital de nível terciário do interior paulista, e avaliar associações e possíveis interferências dos sintomas depressivos no desempenho de papéis ocupacionais. Materiais e Métodos: Para atingir os objetivos da pesquisa foram utilizados o Mini Exame do Estado Mental, a Escala de Depressão Geriátrica, versão abreviada, a Escala de Eventos Vitais e a Lista de Identificação de Papéis Ocupacionais. Os instrumentos foram aplicados a um total de 72 idosos atendidos no Ambulatório de Triagem e Retornos Curtos em Geriatria (GERI) do Hospital das Clínicas da FMRP- USP, sendo estes idosos distribuídos em dois grupos: 32 idosos com presença de sintomas depressivos e 40 Idosos sem sintomas depressivos. Todos os participantes efetuaram a leitura e concordância com o Termo de Consentimento Livre e Esclarecido. Os resultados obtidos não identificaram associação entre sintomas depressivos e desempenho ocupacional de idosos. Ao que parece o envelhecimento traz inúmeras perdas, entre as quais, a perda de papéis ocupacionais de importância. Este trabalho pode instrumentalizar a realização de novas pesquisas. 